\title{
A POLÍTICA COTIDIANA DOS VEREADORES E AS RELAÇÕES ENTRE EXECUTIVO E LEGISLATIVO EM ÂMBITO MUNICIPAL: O CASO DO MUNICÍPIO DE ARARUAMA ${ }^{1}$
}

\author{
Felix G. Lopez
}

\section{RESUMO}

O presente artigo analisa as atividades políticas cotidianas dos vereadores de um município do interior do estado do Rio de Janeiro, relacionando-as 1) à dinâmica institucional entre Legislativo e Executivo municipais e 2) às percepções sociais dos eleitores a respeito da natureza da atividade política. A partir dessa análise, o artigo procura mostrar a indissociabilidade entre esses aspectos e questionar a eficácia das mudanças de natureza institucional como instrumento transformador das relações políticas.

PALAVRAS-CHAVE: política municipal; vereadores; relações entre Legislativo e Executivo; clientelismo político.

\section{INTRODUÇÃO}

A literatura da Ciência Política e da Sociologia Política no Brasil tem apresentado um crescente número de estudos sobre as relações entre os poderes Executivo e Legislativo no país, especialmente nos âmbitos federal e estadual. Os trabalhos da Ciência Política, no entanto, circunscrevem-se à abordagem institucional, em que os valores culturais e as representações sociais têm pouca relevância como variáveis explicativas dos resultados da interação entre os atores políticos. Por outro lado, a literatura institucionalista apresenta poucos trabalhos direcionados à compreensão da dinâmica política nos municípios. Quando muito, a política municipal e sua dinâmica interna servem como exemplo ilustrativo das redes que vinculam os políticos municipais, estaduais e federais. Isso se deve, em parte, à idéia de que a política municipal é menos relevante para compreender o sistema político de maneira mais ampla, além de ter menor importância do ponto de vista teórico ${ }^{2}$.

1 Agradeço aos dois pareceristas anônimos da Revista de Sociologia e Política as sugestões e críticas feitas a este artigo.

2 A observação de Bailey (1971, p. 3) parece adequada para dar conta da relativa escassez de estudos sobre a dinâmica política municipal: "At first sight the investigation of 'small politics' seems a trivial enterprise, one that is,
A relevância da esfera municipal no ordenamento das relações políticas em âmbito nacional é encontrada em estudos clássicos da literatura política brasileira (QUEIROZ, 1976; LEAL, 1997) e em alguns estudos de Antropologia Política (BEZERRA, 1999). Bezerra tentou mostrar que a atuação dos parlamentares federais no processo de montagem do Orçamento Anual da União é fortemente orientada para a transferência de recursos federais às suas bases eleitorais nos municípios. Os vínculos dos parlamentares com seus

perhaps, unworthy of intellectual attention. Reputations and gossip and one-upmanship are the small beer of small people, while our destinies lie in the hands of great men cabinets and shadow-cabinets - who deal or would like to deal grandly with great issues. This view is mistaken. The 'great man-great issues' argument is weak because it confuses description with analysis and ignores the fact that the same principles serve for political competition and political alliance alike in great issues and small" [" $\mathrm{A}$ primeira vista a investigação da 'política pequena' parece um empreendimento trivial, talvez imerecedor da atenção intelectual. Reputações, fofocas e idolatrias [oneupmanship] são a pequena cerveja do povo miúdo, enquanto nossos destinos residem nas mãos dos grandes homens gabinetes e gabinetes secretos - que lidam ou gostariam muito de lidar com tais temas. Essa visão é errada. O argumento 'grande homem-grandes temas' é fraco porque confunde descrição com análise e ignora o fato de que os mesmos princípios servem para a competição política e para a aliança política tanto nos grandes temas quanto nos pequenos" - Nota do revisor].

Rev. Sociol. Polít., Curitiba, 22, p. 153-177, jun. 2004 153 
municípios e a manutenção de suas redes políticas locais ocupam lugar de destaque nas variáveis essenciais para a compreensão da dinâmica política no âmbito federal.

Apesar disso, não parece ter havido estímulo para investigarem-se as dinâmicas políticas que se processaram nos municípios no período de redemo-cratização do país. O presente artigo tem este objetivo: a partir da perspectiva da Antropologia Política, que dirige o foco da análise para variáveis como valores culturais e representações sociais, investigo a relação entre os poderes Executivo e Legislativo em um município do interior do estado do Rio de Janeiro e tento mostrar que essa relação só é inteligível a partir da compreensão da atividade política cotidiana dos vereadores.

O texto está dividido em três seções. Sucintamente, a próxima fornece algumas informações sobre a história política do Município de Araruama e alguns dados sócio-econômicos para contextualizar o cenário em que se desdobra o processo político. A seção seguinte analisa o exercício da política cotidiana pelos vereadores, seus trabalhos de atendimento às demandas dos eleitores e a importância dessa variável para explicar a relação entre Executivo e Legislativo no município. A última seção analisa propriamente a relação entre os poderes Executivo e Legislativo e sugere algumas conclusões, ainda que tentativas ${ }^{3}$.

3 O trabalho de campo foi realizado entre os meses de abril
e dezembro de 2000, ano eleitoral. Embora minha
preocupação não fosse analisar o processo eletivo,
certamente o resultado da pesquisa foi influenciado pelo
momento de sua realização. É válido ressaltar que existem
algumas vantagens em realizar a pesquisa no "tempo da
política" (PALMEIRA \& HEREDIA, 1995; PALMEIRA,
1996). A principal é que nesse período as divergências e os
conflitos multiplicam-se e emergem aos olhos do observador
de maneira mais clara. Por outro lado, esse tempo salienta
os interesses em jogo durante a atividade política cotidiana
dos vereadores, fora do período eleitoral. Sem dúvida, a
proximidade das eleições cria novas situações políticas e
altera padrões de relacionamento, mas, em muitos casos,
acentua aspectos sempre presentes e constitutivos da
dinâmica política local, como a troca de favores e o trabalho
de atendimento dos vereadores. Ao longo do estudo, tomo
como suposto analítico que os atores políticos de Araruama
têm a conquista de votos como horizonte de sua ações
políticas. Em outros termos, eles querem obter ou renovar
seus mandatos. A convivência com parte dessas pessoas
tornou isso bastante claro. Não é por outra razão que me
refiro aos habitantes do município como eleitores e acredito
expressar a racionalidade que orienta o cálculo político na

\section{O CONTEXTO MUNICIPAL}

Araruama é um município do estado do Rio de Janeiro e situa-se na região das baixadas litorâneas, que compreende outros onze municípios. Possui $643 \mathrm{~km}^{2}$ de extensão territorial e dista aproximadamente cem quilômetros da capital. Tem 69090 habitantes e 57928 eleitores (TCE, 2000, p. 31). Em 1998, o produto interno bruto (PIB) municipal foi de $\mathrm{R} \$ 219455$ 000,00 e o PIB per capita, de R\$ 3 176,00. Quanto à contribuição dos setores de atividade para o PIB, o terciário é o responsável por $62 \%$ da riqueza produzida, a indústria responde por $38 \%$ e a agropecuária, por $4 \%$. Em 1996, a população urbana era $78 \%$ do total e a população rural, 22\% (SEBRAE-RJ, 1999, p. 3-4).

Desde 1924, o poder político local revezou-se entre representantes de "famílias tradicionais do município" (BARBOSA, 1996; VIEGAS, 1997): Vasconcellos, Lessa, Raposo, Castanho, Valladares e Carvalho. A exceção foi Altevir Barreto ${ }^{4}$, que em 1977, ao eleger-se Prefeito, rompeu a tradição, uma vez que era um "forasteiro", proveniente de Petró-polis ${ }^{5}$, e não possuía vínculos de parentesco em Araruama. Como observou Viegas (1997, p. 32), “[...] seu governo, contemporâneo das mudanças moti-vadas pela [construção da] ponte Rio-Niterói e do conseqüente aumento do fluxo de pessoas 'de fora' da cidade, é identificado como um tempo de trans-formações e de abertura do acesso ao poder a pessoas que não faziam parte das elites locais. Daí em diante, alternaram-se

interação social entre os vereadores, prefeitos e população. A respeito das razões para estarem na política, nada é dito, já que essa questão demandaria outra pesquisa. Os atores podem estar motivados por interesses econômicos, benefícios materiais ou imateriais - como a criação ou a manutenção de prestígio pessoal, honra ou status. A complexidade de seus motivos não será abordada. Por fim, ressalvo que, se a análise a seguir esteve menos preocupada com as atribuições formais e os preceitos legais da ação dos políticos, $i . e$., variáveis institucionais, isso não significa que elas tenham pouca relevância. Adoto, portanto, uma perspectiva analítica específica menos preocupada com atribuições formais e regimentais do que com a política cotidiana, pragmaticamente desenvolvida pelos atores. Como poderá ser observado, quase toda a literatura utilizada é proveniente da Antropologia Política, não da Ciência Política.

4 Os nomes utilizados neste trabalho são fictícios, salvo nas referências a ex-prefeitos que não estão diretamente relacionados à análise.

5 Município situado na região serrana do estado do Rio de Janeiro. 
prefeitos 'filhos de Araruama' com esse mesmo 'forasteiro"'.
A Tabela I abaixo apresenta os prefeitos municipais e sua ligação com as famílias tradicionais do município:

TABELA 1 - PREFEITOS MUNICIPAIS DE ARARUAMA E RESPECTIVOS MANDATOS (1924-2000)

\begin{tabular}{|c|c|}
\hline PREFEITO MUNICIPAL & MANDATO \\
\hline Plácido Vieira Marchon † & 1924 (não tomou posse) \\
\hline Joaquim de Carvalho Vasconcellos $†$ & $1925-1927$ \\
\hline Luiz Maria Lamas Rabello † & $1928-1929$ \\
\hline Plácido Vieira Marchon † & 1930 (deposto pela Revolução de 1930) \\
\hline Mário dos Santos Alves † & $1930-1936$ \\
\hline Antônio Joaauim Alves Branco † & $1937-1945$ \\
\hline Renato de Vasconcellos Lessa $\dagger$ & $1947-1950$ \\
\hline Graciano Torres Quintanilha † & $1950-1954$ \\
\hline João Joaquim Carvalho Vasconcellos † & $1954-1958$ \\
\hline Antônio Raposo † & $1958-1959$ \\
\hline Adherbal Azevedo Soares $†$ & $1959-1963$ \\
\hline Mário Revelles Castanho † & $1963-1967$ \\
\hline Renato de Vasconcellos Lessa $\dagger$ & $1967-1971$ \\
\hline Armando da Silva Carvalho $†$ & $1971-1973$ \\
\hline Afrânio Valladares † & $1973-1977$ \\
\hline Altevir Barreto $†$ & $1977-1983$ \\
\hline Renato de Vasconcellos Lessa $\dagger$ & $1983-1989$ \\
\hline Altevir Barreto $†$ & $1989-1992$ \\
\hline Henrique C. Valladares & $1992-1996$ \\
\hline Vilmar Oliveira (Meira) & $1997-2000$ \\
\hline Francisco Ribeiro & 2001-2004 \\
\hline
\end{tabular}

FONTE: Secretaria Municipal de Cultura de Araruama (1992, p. 25-26) e o autor.

NOTA: Os sobrenomes em negrito indicam famílias tradicionais do Município. 
Atualmente, a importância das famílias tradicionais e da tradição familiar na política do município é pequena. A expansão demográfica e as transformações econômicas, aliadas ao falecimento de antigos líderes - últimos representantes do período em que o sobrenome era indispensável à liderança política municipal -, foram elementos determinantes para o enfraquecimento da tradição familiar na política de Araruama.

\section{A DINÂMICA DAS RELAÇÕES ENTRE VEREADORES E ELEITORES ${ }^{6}$}

As relações entre o Legislativo e o Executivo municipais só podem ser devidamente compreendidas após analisarmos a importância que o "atendimento" 7 às demandas dos eleitores assume na atividade política cotidiana dos vereadores.

A Câmara Municipal de Araruama é composta por 17 vereadores, que dedicam a maior parte do seu tempo ao atendimento aos eleitores, cujas demandas são, na grande maioria das vezes, de caráter pessoal ou particularista. A prática do atendimento aos eleitores é uma busca de solução para questões pontuais e nela a interação face-aface com o eleitor (no gabinete ou na rua) e com os problemas que o afetam no dia-a-dia é muito importante. $\mathrm{O}$ atendimento é a atividade em torno da qual se desenvolve o trabalho diário dos vereadores no município. Do ponto de vista da racionalidade eleitoral, maximizadora de votos, esse comportamento é coerente, dado que o capital

\footnotetext{
${ }^{6}$ Esta seção utilizou como fonte analítica 36 entrevistas semi-estruturadas que realizei com quinze vereadores e dois ex-vereadores, três ex-prefeitos, alguns funcionários da Câmara de Vereadores, assessores parlamentares e integrantes do poder Executivo. Aproximadamente metade das entrevistas foi gravada, com o consentimento dos entrevistados. As entrevistas com os vereadores foram realizadas, na maioria das vezes, em seus próprios gabinetes. Além disso, consultei o arquivo público da Câmara, que guarda toda a legislação, projetos, emendas e proposições formuladas na Casa, as sessões plenárias gravadas em fitas cassete e grande parte da correspondência dos vereadores. Outra fonte de informações, menos relevante nesta pesquisa, foram os jornais locais. Por fim, realizei observações diárias da atividade política de vereadores na Câmara e fora dela, acompanhando vereadores e assessores em seu trabalho cotidiano. Como a abordagem aqui é interpretativa, a análise das entrevistas e a observação direta da atividade política dos vereadores foram as principais fontes de informação.

7 Termo utilizado por vereadores e assessores.
}

político do Vereador é medido por sua capacidade de atender aos pedidos que lhe são encaminhados.

Entretanto, a maior parte das demandas que o Vereador recebe tem sua solução condicionada ao atendimento por parte do Executivo e de suas secretarias. O Vereador é permanentemente confrontado com uma escolha, que confere inteligibilidade à dinâmica relacional entre Executivo e Legislativo: apoiar o governo e o Prefeito e ter maior possibilidade de eles corresponderem aos seus interesses, ou ser oposição e ter sua capacidade de atendimento cerceada (esse aspecto será desenvolvido na última parte do texto).

Nesta primeira parte descrevo a atividade política cotidiana do Vereador, como ele desenvolve seu trabalho de atendimento e quais as estratégias para sua otimização. Em outros termos, analiso as tarefas em que está empenhado durante sua atuação como político e as condições sociais e institucionais em que essas tarefas inserem-se.

Como ficará evidente, privilegio a dimensão dos valores que orientam as práticas políticas dos vereadores. Seria igualmente importante compreender as expectativas sociais em relação às suas práticas e os parâmetros institucionais que orientam o comportamento dos agentes políticos, mas esses aspectos são tratados apenas tangencialmente devido à limitação de tempo de realização da pesquisa.

Não há dúvida de que os vereadores respondem a parte das expectativas sociais que os eleitores têm em relação a eles, mesmo que nem todas essas expectativas sejam condizentes com a motivação pessoal do Vereador ou com as imposições institucionais. O resultado é uma relação complexa entre modos de ação social distintos ou opostos em que a norma social e a regra legal são divergentes. Como já discutiram, entre outros, DaMatta (1987; 1997; 1998) e Vianna (1987), as relações sociais entre os atores da esfera pública constroem-se a partir da interação de comportamentos motivados por valores que são, não apenas distintos, mas contraditórios. Na esfera política municipal, notadamente na relação entre os agentes políticos e os eleitores, o mundo público das leis impessoais e universais é constantemente confrontado com a necessidade de burlá-lo para atender às demandas do universo privado dos parentes, dos amigos, dos apadrinhados, dos aliados. 
Analisando as formas de interação entre Estado e sociedade, no que denominou de "gramáticas políticas", Nunes (1997, p. 121) observou que, "dependendo do contexto, todos os atores podem utilizar estratégias que contradizem sua retórica pública. [...] Isso é possível apenas porque as [...] gramáticas (clientelismo, corporativismo, insulamento burocrático e universalismo de procedimentos) estão sempre disponíveis, possuem expressão institucional em todas as instâncias e são bastante conhecidas pelos atores sociais, que podem transitar de uma gramática para outra, dependendo do contexto".

Em certo sentido, guardadas as diferenças de complexidade que separam a ordenação institucional nos âmbitos federal e municipal, a observação do autor é aplicável também ao município de Araruama.

O contexto e as circunstâncias sociais em que as ações desenvolvem-se correspondem a modos de agir que se contradizem. Pode-se atuar como político defensor das regras e procedimentos universais concomitantemente ao modus operandi do político que baliza sua ação no idioma da amizade, do favoritismo, da patronagem ou do parenteirismo.

Um exemplo ilustrativo são as declarações que um recém-exonerado funcionário público municipal deu à Comissão Especial de Inquérito (CEI) instaurada em fins de 1998 para apurar demissões irregulares de funcionários da administração por motivos políticos. Seu depoimento relata que “[...] em abril de 1997 foi chamado pelo senhor José, ex-Secretário de Saúde, para responder pelo controle e posterior fiscalização dos exames complementares realizados pela Secretaria de Saúde [...]. Que vinha assim agindo, quando foi comunicada em junho de 1997, pela senhora Lia, que deveria atender os [sic] pedidos dos senhores vereadores Mário, Henrique, Jonas, Souza, Alair, Ricardo e Marcos, sem criar quaisquer dificuldades; sendo assim, procurou o Secretário de Saúde, para que o mesmo confirmasse tal informação, quando o mesmo disse que continuasse agindo da mesma maneira [...]. A partir de então, passou a ser intensamente perseguido pelas senhoras Clara e Maria [...], irmãs do senhor Prefeito ${ }^{8}$. Perguntado de que se tratavam

8 Assim como funcionárias da Secretaria Municipal de Saúde. tais perseguições, o Depoente esclareceu que era pressionado por estas pessoas a autorizar exames fora das normas preconizadas, e que de certo nunca cedeu a tais apelos [...]; por esse motivo, o senhor Prefeito 'pediu a sua cabeça' ao Secretário de Saúde" (CEI, 1999, f. 41).

Entre os componentes da CEI que ouviam o depoente, estavam Mário e Jonas, ambos integrantes do grupo de vereadores que teriam acesso privilegiado à Secretaria de Saúde, por determinação do Prefeito. Ao mesmo tempo, desempenhavam o papel social de integrantes da comissão que se pautava pela defesa "do conceito de administração pública, lastreado nos princípios da legalidade, impessoalidade, moralidade, dentre outros" (idem, f. 1). Observe-se ainda que a recusa do funcionário em atender de maneira prioritária as solicitações de alguns vereadores foi o que determinou a "perseguição" que sofreu e fez o Prefeito "pedir a sua cabeça". Em grande medida, há a percepção, por parte do Prefeito e dos próprios vereadores, de que o atendimento prioritário a alguns em detrimento de outros é legítimo e natural. Isso fica claro quando os vereadores passam a reclamar da falta de critérios do Prefeito para $\mathrm{o}$ atendimento às demandas dos vereadores, pois "mesmo quem é governo não é atendido pelo Prefeito" (LOPEZ, 2001, p. 27).

A Câmara de Vereadores situa-se ao lado da Prefeitura, no centro da cidade. Sua sede abriga os gabinetes dos 17 vereadores, que ficam dispostos em salas contíguas ao longo de um corredor em forma de "L". Além desses gabinetes, há o plenário, onde se realizam as sessões, e algumas salas adicionais que abrigam as demais seções operacionais da Casa, tais como Contabilidade, Coordenadoria Geral da Câmara, Departamento Jurídico, Sala das Comissões Permanentes etc. As sessões plenárias ocorrem duas vezes por semana, com duração regimental máxima de quatro horas. No entanto, é raro que as sessões ultrapassem duas horas, pois o número de proposições encaminhadas é muito pequeno e a maioria dos vereadores, à exceção de dois ou três, dificilmente profere algum discurso ou faz observações sobre as matérias propostas.

Com algumas exceções, a maioria das sessões plenárias é composta por matérias como moções (especialmente moções de aplauso e moções de congratulação), requerimentos e indicações. As 
indicações e as moções são os tipos de proposições mais utilizados. Por meio das indicações, os vereadores fazem o encaminhamento formal de suas solicitações ao Executivo, justificadas como medidas de interesse público. Solicita-se a colocação de braços de luz em vias públicas, calçamento de ruas, construção de creches, escolas, quadras poliesportivas, instalação de telefones públicos, redutores de velocidade e abrigos de ônibus, entre outras coisas. As indicações feitas em plenário são posteriormente encaminhadas ao Executivo que, em deliberação interna, decidirá atender ou não às solicitações. O critério de atendimento, que discuto em outra seção, é um dos principais instrumentos de controle do Executivo sobre o Legislativo, já que " $80 \%$ do atendimento é pautado por critérios políticos e $20 \%$ por critérios técnicos" (idem, p. 28), de acordo com um exChefe de Gabinete da Prefeitura.

Além das indicações, há os requerimentos, que são proposições apresentadas (de maneira escrita ou verbal) pelos vereadores, solicitando informações ao Executivo; sobre as moções, falaremos adiante.

A análise das indicações revela que a maioria dos vereadores possui alguns redutos eleitorais, onde se concentram suas maiores votações. Para esses redutos é feita a maioria das indicações de cada Vereador, o que indica a importância da representação política em termos espaciais e reflete-se na freqüência de moradores dos redutos nos gabinetes dos respectivos vereadores. Em larga medida, os eleitores passam a ver em determinado Vereador o representante do seu bairro, de sua localidade, de sua comunidade 9 .

Em contrapartida, a representação funcional é quase inexpressiva. A não ser no caso de dois vereadores cujas bases eleitorais são associações evangélicas, a representação espacial predomina amplamente. Ocorre um processo muitas vezes espontâneo de fracionamento da atuação de cada Vereador por determinadas áreas do município, o que não implica sua recusa em atuar em outras

\footnotetext{
9 A noção de "comunidade", freqüientemente utilizada pelos políticos locais, refere-se ao bairro ou ao distrito em que o Vereador possui relações sociais mais amplas e maior votação. Contudo, algumas vezes a expressão é utilizada em referência a todos os habitantes do município.
}

regiões. Ao contrário: os vereadores buscam ampliar ao máximo o leque geográfico de sua atuação, mas para isso enfrentam dois obstáculos: a falta de amizade com pessoas influentes na localidade e a limitação da capacidade de distribuir benefícios, direcionados prioritariamente aos redutos mais importantes.

A ausência de representação política a partir dos grupos de interesses funcionais ou classes sociais indica a inexpressividade dessas instâncias para a formação de redes de solidariedade no município. A teoria política dos grupos ${ }^{10}$ não se aplica à realidade municipal: nela impera um sistema social "diadicamente estruturado", em que as relações estabelecidas entre eleitores e agentes políticos estruturam-se na forma de redes diádicas (LANDÉ, 1977b, p. 77). Aqui é preciso fazer uma breve observação terminológica.

O conceito de rede pode ser utilizado no sentido de "network" ou de "web". A network expressa a idéia de ligações mútuas entre díades em toda a sociedade: não há um "ego". A web refere-se ao conjunto de relações pessoais que um indivíduo (ego) possui e utiliza para alcançar fins determinados. A imagem correspondente é semelhante à teia de aranha ${ }^{11}$.

10 Seguindo a definição de Landé (1977b, p. 75-76), na teoria dos grupos "[...] individuals act in politics largely as members of groups. A group is a set of individuals who share an attitude. They act together because they perceive that by doing so they are most likely to attain objectives consistent with the attitude which they share, and thus to gain similar individuals rewards. Groups often [...] consist of persons whose common attitude stems from the fact that they have some similar 'background' characteristic such as sex, age, religion, occupation or social class" ["[...] indivíduos atuam na política muito como membros de grupos. Um grupo é um conjunto de indivíduos que compartilham uma attitude. Eles atuam juntos porque percebem que fazendo dessa maneira é mais provável atingirem objetivos consistentes com a atitude que compartilham e, assim, obterem recompensas individuais similares. Os grupos frequientemente consistem em pessoas cuja atitude comum origina-se do fato de que têm alguma característica em comum, como sexo, idade, religião, ocupação ou classe social" - N. R.]

11 Para uma discussão desses conceitos, cf. Landé (1977b), Barnes (1987) e Mayer (1987). 


\section{ESQUEMA 1 - CONCEITOS DE REDE: WEB OU NETWORK}

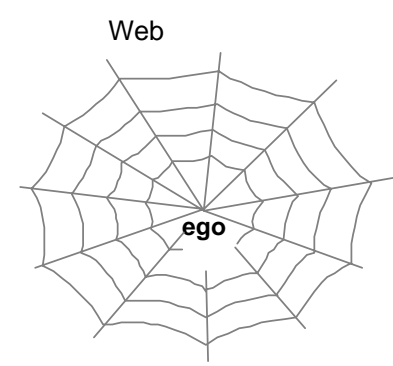

FONTE: Lopez (2001, p. 29).

Nos sistemas diadicamente estruturados em networks, as ações dos egos (os vereadores, por exemplo) são iniciadas pela mobilização de suas webs pessoais para alcançar os objetivos determinados. As webs variam em número e extensão. Um dos condicionantes mais importantes para a ampliação delas é a posse de recursos, materiais ou simbólicos, para distribuir aos seus membros. No caso da política municipal, a densidade e a extensão das webs são determinantes em períodos eleitorais, permitindo ampliar o raio de influência dos vereadores, uma vez que os membros das webs sempre têm sua própria rede de influência. Um eleitor que faça parte da web de um Vereador pode angariar os votos dos amigos e parentes, por exemplo.

Utilizo o conceito de rede no mesmo sentido de Bezerra (1995, p. 45), isto é, para "[...] assinalar o conjunto limitado de contatos diretos e indiretos de uma pessoa que se caracteriza por estar fundado em relações de caráter pessoal. Desse modo, as redes pessoais incluem notadamente aquelas pessoas que estão vinculadas por relações de parentesco, amizade, patronagem, alianças pessoais e conhecimento. Uma pessoa não precisa estar diretamente vinculada a um ego para ser considerada como integrante de uma rede pessoal. Para que isto ocorra, é suficiente que ela mantenha um contato pessoal com alguém que mantenha um contato de mesmo caráter com o ego"12.

12 O conceito de "rede" já foi objeto de ampla discussão, sobretudo entre os antropólogos. Barnes (1987, p. 167) define-a como "um conjunto de relações interpessoais concretas que vinculam indivíduos a outros indivíduos". Essa definição, de acordo com o próprio autor, exclui a

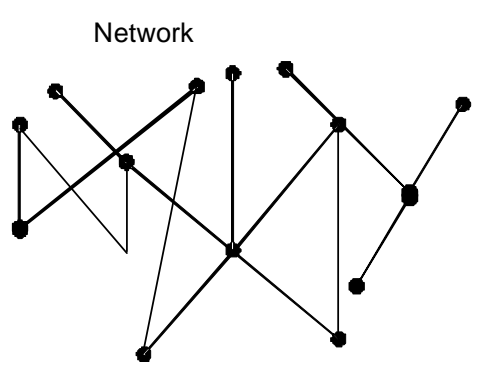

A proposição de indicações é um dos recursos políticos que o Vereador utiliza para demonstrar a seu reduto eleitoral que está trabalhando por ele. Quando a indicação é atendida, o Vereador encaminha a proposição feita em plenário para a pessoa ou as pessoas beneficiadas, a fim de atestar sua mediação em favor delas ${ }^{13}$. Mesmo as indicações que não foram atendidas servem como instrumento de demonstração de interesse e empenho do Vereador em cuidar do interesse do demandante ${ }^{14}$.

utilização do termo para análises que estejam centradas no ator, para as quais ele desenvolve conceitos egocêntricos (estrelas, zonas etc.). No entanto, como o interesse é analisar a importância das relações pessoais criadas e mantidas pelos vereadores na administração municipal e extramunicipal para alcançar determinados objetivos, a definição de Barnes é inadequada.

13 Algumas vezes foi possível observar a assessoria dos vereadores enviando as indicações feitas em plenário para a pessoa ou as pessoas beneficiadas pela intervenção supostamente resultante da indicação feita. Acompanhei, por exemplo, um assessor que deixou com o porteiro de um edifício a indicação de um Vereador pleiteando o reparo do asfaltamento da rua em frente ao prédio. $\mathrm{O}$ assessor solicitou ao porteiro que afixasse a indicação no mural de informações do edifício, a fim de dar ciência, aos moradores, do responsável pela intervenção da Prefeitura.

14 A título de comparação, observo que o uso da indicação, no município, possui a mesma função que a proposição de emendas ao orçamento da União, feitas por parlamentares federais junto à Comissão de Orçamento. Referindo-se a parlamentares que apresentam um grande número de emendas ao orçamento da União, Bezerra $(1999$, p. 77) salienta que, para o parlamentar, mesmo sabendo que pouquíssimas das suas propostas de emenda serão atendidas, "é irrelevante, em último caso, se as emendas ordinárias são aproveitadas pela Comissão. Elas prestam- 
Apesar de a indicação ser um documento formal utilizado pelos vereadores para encaminhar solicitações ao Executivo, nem todos adotam esse procedimento. Uma análise do número de indicações feitas entre os anos de 1997 e 1999 mostra como pode variar sua quantidade entre os vereadores $^{15} \mathrm{e}$ o fato de alguns deles encaminharem um número menor de indicações formais não significa que elas não ocorram e sim que os vereadores também se valem de interação informal com o Prefeito, seus assessores e secretários de governo. Esse procedimento é tanto mais utilizado quanto maior a proximidade pessoal do Vereador com a burocracia das secretarias de governo responsáveis pelas demandas que ele encaminha.

Ao lado do encaminhamento de proposições em plenário, a assessoria parlamentar é outro aspecto relevante no desempenho político-eleitoral dos vereadores. Cada Vereador pode nomear três assessores: um chefe de gabinete, um assessor parlamentar e um agente de gabinete. À distinção formal (e salarial) dos cargos não correspondem diferenças nas tarefas cotidianas: todos podem fazer de tudo. Alguns podem assumir maiores responsabilidades, como atender às demandas encaminhadas aos vereadores sem sua intermediação. Como um assessor descreve, "embora os outros assessores do gabinete façam o atendimento [dos eleitores], o atendimento feito por eles é mais básico. Levar uma pessoa à Prefeitura para dar entrada em um processo, conseguir um parcelamento [das dívidas]... Aqueles mais complicados acabam vindo para minha mão, até porque eu tenho já os meus contatos estabelecidos nas mais diferentes áreas para conseguir ajudar essas pessoas" (LOPEZ, 2001, p. 32).

Como se vê, ter contatos é um importante critério de distinção entre os assessores. De modo

se, sobretudo, à demonstração de interesse e dedicação do Parlamentar aos municípios, entidades e demandantes". Assim como no caso dos deputados federais, este é um dos usos da indicação diante dos eleitores: demonstração de que o Vereador interessa-se pelo atendimento.

15 Número de indicações feitas por cada Vereador (identificados por letras) entre 1997 e 1999: Vereador $A=39 ; \mathrm{B}=$ $96, \mathrm{C}=27, \mathrm{D}=96, \mathrm{E}=90, \mathrm{~F}=51 ; \mathrm{G}=42 ; \mathrm{H}=12 ; \mathrm{I}=186$; $\mathrm{J}=21 ; \mathrm{K}=24 ; \mathrm{L}=57 ; \mathrm{M}=336 ; \mathrm{N}=456 ; \mathrm{O}=69 ; \mathrm{P}=366$; $\mathrm{Q}=60$. geral, sua nomeação responde a uma das seguintes motivações: vínculo de parentesco ou amizade; inserção na comunidade e retribuição por favores ou ajuda prestada em campanha. O conhecimento técnico (dos regimentos e das leis, por exemplo) é um critério quase desprezível para a escolha da assessoria. Por outro lado, a escolha de familiares ou parentes próximos talvez seja o critério primordial.

A nomeação de parentes para cargos públicos é quase uma obrigação social, dada a expectativa fortemente presente nas representações dos próprios familiares e da sociedade em geral, como Bezerra (1995) e Queiroz (1976) já ressaltaram. Por outro lado, a concessão de empregos aos parentes gera um sentimento de dever cumprido. Opor-se a ela pode gerar conflitos pessoais. "A questão familiar é muito difícil. A minha família, por exemplo, é muito grande. Eu tenho mais de cem pessoas [entre parentes de primeiro grau]. E eu tenho pessoas na família que não votaram comigo porque eu não consegui emprego para elas na legislatura passada. Mas o que é que eu vou fazer?" (LOPEZ, 2001, p. 32).

Em algumas situações, empregar parentes responde também à necessidade de confiança imposta pelo contexto de atuação dos próprios políticos, pois a lealdade nas relações de trabalho é fundamental para entender as relações do político com sua assessoria, suas estratégias de nomeação e, mesmo, as razões do nepotismo.

Um dos exemplos mais notáveis do uso da parentela como instrumento de controle político é dado pelo Prefeito que, para restringir o acesso dos seus adversários às secretarias de governo, mobilizou a rede de lealdade construída pela nomeação de seus próprios parentes em diversos setores da administração ${ }^{16}$. Como indicou Wolf (1974, p. 12), "a cooperação entre parentes é importante [...] em operações de destruição política, em que são empregados parentes privativamente para limpar a área de figuras políticas secundárias".

\footnotetext{
16 Aqui há uma comunhão de interesses econômicos (fornecer emprego), políticos (ter controle da burocracia) e imposições sociais (nomear os parentes).
} 
Como o atendimento ao eleitor - crucial na atividade política - é muitas vezes realizado diretamente pelo próprio assessor, a lealdade é a garantia de que o assessor de fato atenderá o eleitor em nome do Vereador, vinculando o favor realizado ao parlamentar para quem trabalha. Essa é uma das razões por que é preciso ter assessores leais. Senão, há o risco de que o próprio assessor capitalize a gratidão pelos favores prestados. "O Vereador não consegue atender à demanda. É muita coisa. Aí, o que é que acontece? O Vereador não pode estar ali [no gabinete] o tempo todo. Senão o cara [eleitor] não fala contigo [assessor]. Vai direto ao Vereador. E fica ruim para o Vereador dizer não! Então eu fazia esse papel de intermediário. De mediador da situação. Dava as desculpas. Falava, por exemplo, 'Pode me dar aqui [o pedido] que o Vereador resolve'. Era eu que resolvia, mas falava que era o Vereador: 'Olha, o Vereador mandou entregar isso aqui para o senhor'. O Vereador, às vezes, nem sabia que o cara tinha ido lá" (LOPEZ, 2001, p. 33).

O risco de "traição" pelos assessores foi mencionado diversas vezes como justificativa para o emprego de parentes na assessoria. O nepotismo, na verdade, responde às necessidades de um sistema fundado nas relações de lealdade e confiança pessoal, o que não significa que o emprego de parentes não seja motivado por outras razões, especialmente as financeiras. Essas razões financeiras são também repetidamente mencionadas para o emprego de parentes na Câmara de vereadores ou outras áreas do setor público municipal.

Os assessores têm um papel importante no desempenho político dos vereadores. Eles são encarregados da redação das proposições encaminhadas ao Plenário, do atendimento aos eleitores que vão ao gabinete, da realização de serviços e atendimento às demandas nas ruas e de aumentar o número de eleitores do seu Vereador, por meio da ampliação da sua própria rede de contatos. Cada Vereador delega determinadas funções a seus assessores de acordo com critérios pessoais.

Se a escolha de um ou mais parentes como assessores tem grande importância para o Vereador, também é importante nomear pessoas que tenham conhecimento e inserção na comunidade, que tenham influência, amigos - que tenham, enfim, relações pessoais que se traduzam em votos. Assim, o assessor também é definido por seu poten- cial como cabo eleitoral, pois o empenho em maximizar as possibilidades eleitorais do seu Vereador nem sempre é condição suficiente para a escolha: é preciso ter a "entrada na comunidade", fator indispensável para mobilizar um número significativo de eleitores (para votar e trabalhar) durante o período eleitoral. A escolha dos assessores pode ter, nesse sentido, um efeito multiplicador de votos.

Como ressaltou um dos vereadores, "A minha assessoria me dá retorno político, são pessoas que tem acesso à comunidade e têm influência, contato, conhecimento até para que futuramente possam trazer o retorno - porque eu tenho que divulgar o meu trabalho lá fora. [...] Você tem que botar uma pessoa capacitada, mas se for olhar só pelo lado da capacidade da pessoa, você fura o lado político. E político vive de quê? De acesso à comunidade, trabalho que possa dar retorno, dar voto" (idem, p. 35).

Buscam-se alianças com pessoas que tenham possibilidade de "transferir" votos para o Vereador, i. e., de o Vereador obter votos graças aos vínculos do eleitor com o assessor. O interesse em saber quem é o Vereador, o seu partido ou plataforma política é, nesses casos, irrelevante para o eleitor.

Legalmente, os vereadores têm direito a três assessores, mas, à exceção de dois, tinham eles uma assessoria mais ampla. Em primeiro lugar, há acordos informais estabelecidos entre os assessores e o Vereador no sentido de que os assessores dividam o seu salário com outras pessoas, que passam a integrar a assessoria. Ademais, os vereadores possuem "cotas" - também informalmente estabelecidas - para indicação de funcionários na Câmara Municipal. Essas “cotas” são franqueadas aos vereadores que apoiam a Mesa Diretora da Câmara, em eleição bienal. Os cargos preenchem uma dupla função para os vereadores: permitem que eles aumentem sua rede, ampliando seu raio de influência política, ao mesmo tempo em que servem como moeda para saldar as dívidas morais contraídas ao longo de sua trajetória política e que, de modo geral, envolvem a necessidade de, com empregos e benefícios aos parentes, retribuir a ajuda recebida.

Um dos vereadores, explicando como decide as indicações que faz, observa: "O critério que eu utilizei [para indicação da assessoria e outros cargos] foi: as pessoas que estiveram próximas a 
mim e acompanharam a minha campanha [para Vereador]. Por exemplo: tem um rapaz que a três meses da campanha falou: 'Vereador Francisco, eu posso te ajudar? Eu tenho um carro, boto um som [para fazer propaganda política pela cidade], você me dá só a gasolina'. Então eu posso deixar de ajudar essa pessoa se eu tiver a oportunidade de arranjar um emprego na Prefeitura? Eu tenho que ajudar essa pessoa. [...] Vou indicá-la. Eu tenho que chegar para o Prefeito e dizer: 'Olha, se você tiver a oportunidade de ajudar esse meu amigo, você me ajuda"” (idem, p. 36).

A maior parte do tempo dos vereadores é dedicado ao trabalho de atendimento às diversas demandas dos eleitores, a maioria de caráter pessoal. Os atendimentos respondem às expectativas dos eleitores, já que o político é a pessoa legitimamente encarregada de realizar a distribuição de benesses públicas, uma vez empossado. "O Vereador é, principalmente, uma figura de referência. Ele é a pessoa procurada para qualquer tipo de problema. O Vereador não é visto como o legislador, salvo em raras exceções. [...] A pessoa não olha o Vereador como um parlamentar, o fiscal das atividades administrativas do Poder Executivo, o cara que vai fiscalizar a aplicação das posturas municipais, que vai propor novas regras, novas leis... Na grande maioria das vezes, a grande maioria das pessoas olha o Vereador como aquele cara que tem que ser o seu representante ao nível de [sic] resolver os seus problemas pessoais, fruto até do grande problema social que a gente vive" (idem, p. 37).

As demandas dos eleitores podem incluir remédios, marcação de consultas em hospitais, emprego, dinheiro para pagar contas, passagem de ônibus, material de construção, agilização de processos na administração, abrigos em ponto de ônibus e diversos outros exemplos: "Aqui, pedem da peruca ao remédio. Eu já tive pessoas pedindo instrumentos musicais, dentadura, óculos, olho de vidro, peruca, tijolo, telha, cimento. Pedem tudo. Tudo que bate na cabeça [do eleitor], eles acham que o Vereador tem que atender e é mais fácil vir ao Vereador que ao Prefeito. [...] Com essa carência toda, nós somos o pára-raios" (ibidem).

A concepção sobre representação política é similar à descrita por Chaves (1996, p. 135), referindo-se a Buritis (MG). Para a autora, "pelo voto, o político é investido no cargo - garantia de acesso a recursos que deve distribuir sob a forma de concessão de 'benefícios' ou 'favores'. Canal de distribuição, ele é percebido como doador, benfeitor. O político legitima-se nesse papel”.

Embora a forma de realizar o atendimento seja peculiar a cada Vereador, o objetivo de "amarrar"17 o eleitor e conseguir sua adesão é a razão motivadora de grande parte da disputa que se observa na arena política municipal, seja na própria Câmara - pela formação dos grupos políticos e facções -, seja na relação entre os vereadores e o Poder Executivo. Assim, o sucesso dos vereadores em atender às demandas encaminhadas depende de seu acesso à administração pública ${ }^{18}$.

Mencionei que o Vereador é a pessoa investida da obrigação de atender às demandas dos eleitores. Há nos eleitores a percepção de que, se por um lado o atendimento às demandas depende do acesso do Vereador à administração municipal, por outro, o fato mesmo de tornar-se Vereador, estar no cargo é, em si, um atributo que lhe confere parte dos acessos $^{19}$. Ao ser empossado, o Vereador adquire um status que lhe confere, junto aos funcionários da administração pública, a legitimidade para requerer e solicitar procedimentos, realizar pedidos, encaminhar processos, intervir em rotinas administrativas - em suma, fazer o seu trabalho político diário, sem estar submetido à mesma rotina que as outras pessoas. Mas cada Vereador possui graus e loci de acesso diferenciados, o que produz entre eles uma informal divisão do trabalho: cada

17 Para usar a expressão de um dos assessores parlamentares entrevistados.

18 Como destacou Diniz (1982, p. 217-218), a política fundada nos termos da amizade, da patronagem e do parentesco é "um campo para iniciados, inacessível sem a interferência da rede de relações pessoais".

19 Kuschnir, analisando as atividades políticas de uma Vereadora da cidade do Rio de Janeiro, salienta que "ter acesso é o que diferencia os políticos e, em especial, os parlamentares, das demais pessoas. O acesso é um bem escasso e que não pode ser comprado, mesmo por quem tem muito dinheiro. Para se obter acesso, é preciso entrar para a política" (KUSCHNIR, 1998, p. 237; grifos no original). 
um tem maior acesso a setores específicos da administração ${ }^{20}$.

As redes de relações pessoais construídas dentro de setores da administração pública são uma das principais estratégias de maximização da capacidade de atendimento. Essas redes podem basear-se na amizade, na patronagem, no parentesco ou em alianças políticas. É importante conferir maior clareza aos conceitos para que eles ajudem a compreender como as redes são acionadas e de que forma elas são mobilizadas, de acordo com os fins desejados. Dessa forma, por meio do vínculo de amizade, pela ligação estabelecida com o funcionário, o Vereador consegue prioridade de acesso aos recursos, sem ficar em posição de dependência diante desse funcionário. Ainda que na maioria das vezes a ajuda do funcionário seja recompensada e retribuída pelo Vereador (na medida em que a reciprocidade é um sine qua non para a manutenção da relação), o vínculo estabelecido não se baseia na dependência política ou pessoal, pois não há assimetrias na relação. É a assimetria de poder (econômico ou político), prestígio ou status que instaura a dependência pessoal. Essas assimetrias são a base de sustentação das relações de patronagem ${ }^{21}$, pois a relação estabelecida - mesmo sendo de ajuda recíproca - apresenta desigualdade nos termos da troca, permitindo a uma das partes a subordinação da outra, sob pena de suspensão dos benefícios concedidos. Um exemplo é a indicação de pessoas para empregos públicos. Muitas vezes, tais

20 Os acessos não se limitam ao setor público municipal. Um exemplo de como eles estendem-se ao setor privado é a possibilidade, franqueada a alguns vereadores e principalmente ao Prefeito, de fazer com que pessoas sejam contratadas por determinadas empresas privadas. Do Gabinete do Prefeito foram expedidos, em 1998, em torno de mil ofícios a empresas privadas solicitando a alocação de determinadas pessoas em seus quadros de funcionários.

21 De modo geral, as relações de patronagem são definidas como relações informais, em que há assimetria de poder, prestígio ou status, com obrigações recíprocas e, na maior parte das vezes, personalizadas. Os vínculos criados são relativamente contínuos, conquanto flexíveis. Tais relações emergiriam sobretudo em contextos em que há controle rígido ou escassez na distribuição de recursos (materiais ou imateriais). Nesse sentido, o controle da distribuição é um dos elementos cruciais para a manutenção do poder social dos patrões em relação aos clientes (cf., entre outros, GRAZIANO, 1977; SCOTT, 1977; SILVERMAN, 1977). indicações atendem ao interesse do Vereador em facilitar o seu acesso a um setor administrativo específico. Mesmo havendo reciprocidade - pois o Vereador concede o emprego e o funcionário, as benesses públicas -, há uma inegável assimetria de poder, fundada na dependência do funcionário em relação ao Vereador, que é o responsável pela manutenção do emprego do funcionário.

As redes de parentesco resultam da obrigação social de ajudar os parentes. Se a alocação de parentes em cargos públicos representa uma obrigação (social) de quem o faz, a "ajuda" que se recebe em troca é uma norma social. Como observou Bezerra (1995), se a reciprocidade é voluntária na relação de amizade, na relação de parentesco ela é prescrita.

A distinção conceitual entre essas relações sociais é mais analítica que empírica, pois relações de amizade, patronagem e parentesco podem sobrepor-se, o que efetivamente ocorre na maioria das vezes. O recurso de distingui-las analiticamente tem como finalidade perceber a especificidade das motivações que orientam as relações entre burocracia, eleitores e agentes políticos, encobertos pelo conceito catch-all de "rede pessoal".

Os acessos à administração são resultado de estratégias de criação de relações pessoais utilizadas pelos vereadores. Muitas vezes, é preciso cultivar a relação. Como menciona um dos vereadores: "A principal estratégia [para criar e manter privilegiados canais de acesso na burocracia] que se pode ter é a confiança da pessoa em você. Não existe outro tipo de rede que possa se formar. Pode até ser que existam outras. Até financeiras, vamos dizer. Mas não é o meu caso. Comigo é pela amizade e pela confiança. Então, às vezes, é aquilo que eu costumo dizer, ganhar a confiança é demorado. É muito mais demorado do que o camarada chegar e dizer: 'Ah, fulano, eu vou te dar um maço de cigarros se você conseguir isso para mim. Vou te dar uma caixa de bombons se você conseguir isso para mim" (LOPEZ, 2001, p. 41).

Uma das principais estratégias de criação e manutenção de redes pessoais na administração pública municipal é a prestação de homenagens e honrarias. O grande número de moções de aplausos e congratulações, bem como a concessão de títulos de cidadania municipal - a maior honraria 
concedida pelo poder público do Município -, atestam sua importância estratégica. A moção é uma proposição encaminhada ao plenário com o objetivo de exaltar as realizações e qualidades de determinada pessoa ou instituição, ou mesmo uma data comemorativa que seja relevante para essa pessoa ou instituição. Nesse sentido, a moção é utilizada amplamente, por grande parte dos vereadores, como forma de $\operatorname{criar}^{22}$, afirmar, renovar ou celebrar laços de amizade ou aliança com membros da administração pública (com quem mantém relações ou pretende manter) e eleitores em potencial.

Por trás da honraria está a sempre vislumbrada possibilidade de, por meio do elogio, vincular o homenageado ao Vereador, criando uma dívida moral. "A troca de homenagens é uma das formas de celebrar e sedimentar as relações de acesso" (KUSCHNIR, 1998, p. 263).

Dado que os acessos são criados e mantidos por meio de relações pessoais, um instrumento eficaz para maximizá-los é a indicação de amigos para cargos públicos, especialmente onde a distribuição e a disputa pela prerrogativa de fazer indicações para empregos públicos são cruciais para definir as relações entre grupos e facções na política municipal. Em primeiro lugar, premiar alguém com um cargo é a forma mais eficaz e segura de vincular o eleitor que o recebe ao Vereador que o concede ${ }^{23}$. É, por outro lado, uma forma de "aliviar" o Vereador das promessas de emprego feitas em campanha e a possibilidade de quitação da dívida (moral) contraída: "[Dar] o emprego é um alívio para o Vereador que prometeu empregos às pessoas que o ajudaram politicamente. Ele é a garantia de que a pessoa já foi

22 "Se amigos produzem presentes, os presentes produzem amigos" (SAHLINS, 1977, p. 137).

23 A incerteza dos vereadores quanto ao voto dos eleitores estimula-os a criarem diversas estratégias para "obrigar" o eleitor a votar neles. Tais estratégias nunca asseguram plenamente que o voto do eleitor será computado em favor do candidato a quem ele assegurou a sua lealdade, mas é, quando menos, uma forma que o Vereador encontra de minimizar as incertezas. Um exemplo, entre vários que envolvem essa racionalidade, é o de um Vereador que, para conseguir os votos dos fiéis de uma igreja, prometeu doar cadeiras novas para ela. No entanto, disse-me, doaria a metade antes e a outra metade depois das eleições, o que serviria como instrumento de pressão para que de fato ele conseguisse os votos daquele grupo. recompensada" (LOPEZ, 2001, p. 41).

Os empregos públicos constituem um instrumento crucial para a consolidação das redes pessoais no município. Se não é considerada a importância dos cargos, perde-se um importante elo na compreensão da dinâmica relacional entre Executivo, vereadores e eleitores ${ }^{24}$. Como já foi mencionado, a formação das redes de acesso à administração é importante para maximizar a capacidade de atendimento às demandas dos eleitores. Em última instância, é a capacidade de atendimento que determina o sucesso político do Vereador. "O povo, em função até da própria condição social, acha que o Vereador, por ser Vereador, tem um bom salário e tem que atender à compra do remédio, arrumar um médico, mandar para o Rio de Janeiro - uma coisa que não é dever do Vereador. Isso é um dever da Secretaria de Saúde. Mas, por eles não fazerem, nós acabamos sendo obrigados a fazer. E se nós não fizermos? Nós passamos a ser tachados como que não fazemos nada, que roubamos, que não sei o quê [...] e acaba se prejudicando $[s i c]$. E dificilmente você vai se reeleger" (idem, p. 45).

Há uma nítida associação entre sucesso político e capacidade de dar assistência e atender às demandas dos eleitores. Essa relação permite-nos pensar a Câmara Municipal como locus de atuação de políticos travando uma disputa pela generosidade, uma disputa em que todos concorrem incessantemente para maximizar a distribuição de favores aos seus demandantes, pois sabemos que o seu prestígio político está vinculado ao volume de seu atendimento. Não é à toa que, entre os

\footnotetext{
24 Queiroz mostra que a utilização dos empregos públicos como dádivas a serem distribuídas entre amigos e eleitores foi sempre importante: "Quanto ao aspecto administrativo tomado pelos benefícios dispensados aos eleitores, todos os documentos [...] mostraram claramente que, a partir da Independência do Brasil, os postos administrativos e os lugares no funcionalismo público passam a agir como novas fontes de benefícios a serem distribuídos. Por isso se tornou tão importante para os mandões dominar as estruturas locais, regionais e até nacionais: tinham em seu poder maior soma de lugares a distribuir e, portanto, de beneficiados com a gratidão dos quais podiam contar. E a gratidão destes era tanto mais ativa quanto no país existiam poucas possibilidades de emprego; deixando de lado a estrutura agrária e a comercial, nada mais existia para os indivíduos exercitarem suas atividades econômicas a não ser os empregos públicos" (QUEIRÓZ, 1976, p. 174-175).
} 
políticos, a noção de trabalho confunde-se com a prática do atendimento e da assistência social. Assim, na terminologia local, os participantes da arena política costumam mencionar que o candidato A ou B foi bem votado porque teve "um trabalho muito bom durante os quatro anos", idéia que se expressa na passagem abaixo: “'Taí”, Meira [nome do Prefeito]! Vereador de dois mandatos, dos mais votados ${ }^{25}$. Foi única e exclusivamente um assistencialista. Nunca teve atuação parlamentar [...]. Só fazia indicação. [...] Quer dizer, a essência do Poder Legislativo não é essa. E, no entanto, é um peso político na cidade hoje, pelo trabalho social que faz, fruto de uma sociedade de grandes carências sociais [...]. Então, quem ganha é aquele que vai por aí e é reconhecido às vezes pelo próprio cara que não depende dessa mão estendida. Mas o cara tem reconhecimento por Fulano de Tal. 'Fulano de Tal é um Vereador bacana! Ajuda o pobre'. Geralmente é isso que você ouve: 'Fulano de Tal é trabalhador para caramba'. Mas o 'trabalhador' não é pelo que ele faz aqui dentro" (idem, p. 46).

Cabe ainda entender as formas pelas quais o Vereador concebe a sua atuação e suas motivações em relação ao atendimento às demandas dos eleitores e quais as condições estruturais que o sistema em que se insere impõe nesse sentido.

Como vimos, os vereadores e sua assessoria passam a maior parte do tempo atendendo o eleitor e tentando encaminhar as demandas recebidas. Isso ocorre no seu gabinete, na rua e até em sua residência. Cabe aqui uma comparação. Kuschnir (1998), inspirada em Marcel Mauss, ressalta a concepção, peculiar ao político, do atendimento ao eleitor como um dever ${ }^{26}$. Referindo-se à idéia que uma Vereadora da cidade do Rio de Janeiro tem acerca do próprio trabalho junto às pessoas de sua comunidade, a autora procura mostrar que "na concepção [da Vereadora], a obrigação de atender é constitutiva da política" (idem, p. 333).

25 O Prefeito foi Vereador do Município nas duas legislaturas anteriores à sua eleição para o Poder Executivo.

26 No mesmo sentido, Bezerra (1999) mostra que, em outro patamar de atuação política, os parlamentares federais concebem a obtenção de recursos para seus municípios como uma obrigação.
Em Araruama, a representação social dos atores políticos é similar: "O cidadão, quando bate à sua porta, não tem que ser necessariamente um eleitor, ter um título. Ele vem porque está precisando. É a nossa obrigação, como representantes do povo, pagos pelo povo. Nós temos que atender" (LOPEZ, 2001, p. 47); "[...] pede-se coisa que não é do Vereador, mas acontece de virem pedir, como é o caso dos remédios. E nós estamos aqui para atender, na medida do possível. O Vereador é eleito pelo povo, e esta aí para atender" (ibidem); "[...] é muito complicado ficar distinguindo pessoas. Até mesmo porque, às vezes, [...] você sabe até que aquela pessoa não tem tendência a votar em você, mas você se sente na obrigação de ajudar. Às vezes, a pessoa não merece, mas a família está passando por dificuldades e você vai e ajuda, até por uma questão humanitária, mesmo" (idem, p. 48).

Se, por um lado, o eleitor considera obrigação do Vereador atender a suas demandas, por outro essa concepção está incorporada à representação que o Vereador tem de sua própria atividade política. A obrigação de atender é dada por motivações distintas, desde a gratidão por ajuda recebida (em campanhas, por exemplo) até por "questões humanitárias". O atendimento, no entanto, possui regras implícitas, explicitadas apenas para os membros do grupo que acompanha o Vereador. Entre as principais está aquela presente em toda economia da dádiva: o atendimento, o favor e a ajuda são sempre concessões aparentemente generosas, desinteressadas. Assim, mesmo que a motivação para atender responda a critérios diversos, não há dúvida de que a dinâmica da relação entre eleitor e Vereador, assim como de grande parte da administração pública, está inserida no circuito da dádiva e em sua lógica específica. A dádiva é o operador que vincula e obriga, estabelece e renova alianças. Ela é constitutiva das relações políticas no município.

O depoimento de um Vereador resume toda a ambigüidade da dádiva: "Eu acredito na gratidão. E nunca me dei mal. Nunca na minha vida perguntei para a pessoa: 'Você vota onde?'. Eu sou da seguinte política: atender sempre que for possível. [...] a gente, quando presta um favor, não tem que estar pensando no retorno. Se o retorno vier, ótimo. A gente pode até perseguir o retorno. Futuramente, na época de uma eleição, pode procurar uma pessoa [...]: 'Fulano, se você 
puder, agora sou eu que estou precisando de uma ajuda [...]'. Nunca você deve fazer o favor na certeza de que aquilo é uma troca. Se encarar como troca, você está perdido" (ibidem).

Como ressaltou Bourdieu (1996, p. 7): “o caráter primordial da experiência do dom é, sem dúvida, sua ambigüidade: de um lado, essa experiência é (ou pretende ser) vivida como uma rejeição do interesse, do cálculo egoísta, como exaltação da generosidade, do dom gratuito e sem retribuição; de outro, nunca exclui completamente a consciência lógica da troca".

Os vereadores estão inseridos em um circuito de trocas que, mesmo a contragosto, impele-os a atuarem da maneira como atuam, atendendo às demandas. A clara percepção que todos têm da falta de expressão eleitoral que a recusa ao assistencialismo traria obriga-os a atuar no mesmo sentido. A dinâmica da competição interna é implacável, pelo menos para os que pretendem a reeleição. A distinção feita por Kuschnir (1993) entre políticos "ideológicos" e políticos "assistencialistas", na Câmara de Vereadores do Rio de Janeiro, não se aplica ao Município de Araruama. Não há espaço para políticos orientados em termos ideológicos, se por isso entendemos um comportamento orientado por linhas estabelecidas nos programas dos partidos políticos. Fora do assistencialismo não há salvação.

Todos sabem que o sucesso e o reconhecimento político é dado pela expressão do seu trabalho social, noção "nativa" que engloba toda sorte de favores. A busca da maximização do atendimento implica, ao lado das estratégias mencionadas acima, a necessidade de construir relações amistosas com membros do Executivo municipal (especialmente o Prefeito) e estabelecer vínculos com deputados (estaduais e federais), permitindo a expansão da rede de acesso para além da circunscrição municipal. Nesse sentido, analisar a relação entre deputados, vereadores e prefeitos seria bastante proveitoso ${ }^{27}$.

27 Em um dos capítulos da minha dissertação, fiz uma análise nesse sentido, baseado nos exemplos de Araruama (cf. LOPEZ, 2001).

\section{AS RELAÇÕES ENTRE EXECUTIVO E LEGISLATIVOEMARARUAMA}

As relações entre o Executivo e o Legislativo no Município de Araruama configuram-se a partir da subordinação do segundo ao primeiro.

Kuschnir (1993; 1995), de modo similar, mostrou que os vereadores da cidade do Rio de Janeiro dependem do Executivo para materializar o atendimento aos seus eleitores. A falta de capacidade do Legislativo de fiscalizar o Executivo expressava-se, entre outros aspectos, na dependência dos vereadores em relação à capacidade de atendimento às suas demandas, feitas pelos eleitores - no que dependem do Executivo. Se, ao desempenhar o papel de broker, o Vereador "garante uma ascendência sobre a população, em relação ao Executivo ocorre exatamente o contrário" e, portanto, "manter e alimentar a relação com o Poder Executivo é o que garante ao seu papel de Vereador o prestígio, junto aos eleitores, de agente da mediação" (KUSCHNIR, 1993, p. 116).

Encontrei o mesmo tipo de lógica e dinâmica relacional descrita por Kuschnir em relação ao Legislativo municipal da cidade do Rio de Janeiro. $\mathrm{O}$ atendimento à demanda dos eleitores, concedido sob a forma de dádivas, é a motivação justificadora da submissão do Legislativo ao Executivo, não só pelos custos políticos que a oposição pode implicar mas também porque "a função de 'fiscal' do Executivo tende a ser diminuída frente à sua pouca expressividade junto à população" (ibidem).

A título de comparação, é interessante observar a relação entre Executivo e Legislativo no nível federal, como analisada por Bezerra (1999). Para esse autor, a partir de uma certa concepção específica que os parlamentares têm de representação política, a importância da obtenção de recursos federais para as suas bases eleitorais é crucial e essa é a principal razão da subordinação do Legislativo ao Executivo. No que tange à liberação de recursos das emendas individuais dos deputados federais ao Orçamento Anual da União, "o controle do governo sobre a execução orçamentária assegura seu poder em relação aos parlamentares, sobretudo junto àqueles que têm interesses em garantir a transferência de recursos federais para suas redes políticas" (idem, p. 181).

A lógica que estrutura a relação entre os dois 
poderes, nas situações mencionadas acima, é a mesma. O comportamento dos parlamentares orienta-se fundamentalmente para as demandas dos seus eleitores e responde, portanto, às suas expectativas sociais. $\mathrm{O}$ fato de as demandas centrarem-se mais nas necessidades materiais e menos na produção de leis torna o Parlamentar dependente daquele que abriga a possibilidade de efetivar suas demandas: o Executivo. Conseqüentemente, o Executivo utiliza-se dessa prerrogativa para, conforme seu próprios interesses, exercer controle sobre o Legislativo e subordiná-lo.

Em Araruama, por ser menor a máquina burocrática (o que possibilita maior controle) e por ser mais amplo o controle sobre os atos alheios, a assimetria de poder entre os dois poderes é mais explícita e "naturalizada", porque há, implicitamente, conformismo dos vereadores da "oposição", que aceitam que sua posição política implicaria falta de acesso aos recursos públicos. Para os vereadores da "situação", a idéia de que devem ser privilegiados em relação aos demais emerge não só nos discursos públicos e nas entrevistas como também nas críticas - públicas ou não dirigidas ao Executivo, por este não atender "nem mesmo a "situação", i. e., os governistas.

A dinâmica da cooptação de vereadores por parte do Executivo pode esclarecer melhor esse processo. Quando o Prefeito foi eleito (pelo Partido da Renovação Popular - PRP, para a gestão 19972000), não elegeu nenhum Vereador da coligação partidária que o apoiou ${ }^{28}$. Foram eleitos onze vereadores do grupo do ex-Prefeito Henrique Valladares (Partido Democrático Trabalhista PDT), três vereadores do grupo do ex-Prefeito Altevir Barreto ${ }^{29}$ (Partido do Movimento Democrático Brasileiro - PMDB) e três vereadores ligados ao grupo de Francisco Ribeiro (candidato derrotado nas eleições de 1997), então filiado ao PFL (Partido da Frente Liberal). Havia, portanto, dezessete vereadores que inicialmente se apresentavam como oposição ao governo. Mas, nos primeiros meses da legislatura, o Prefeito já contava com o apoio desses dezessete vereadores, segundo observação deles mesmos e notícias veiculadas na imprensa local. A adesão ao Prefeito era fluida e mudava conforme os acordos faccionais. As facções foram alterando-se em sua composição inicial e, a partir do segundo ano de mandato, tomaram uma nova forma: a facção de seis vereadores ligados ao ex-Prefeito Valladares; uma nova facção de seis verea-dores, que respondiam às orientações do Deputado Estadual Roberto Araújo e a facção do Prefeito em exercício, composta por cinco vereadores.

TABELA 2 - FILIAÇÃO PARTIDÁRIA DOS VEREADORES ELEITOS (1997 E 1999)

\begin{tabular}{|c|c|c|}
\hline VEREADOR & 1997 & 1999 \\
\hline A & PST & PSDB $^{*}$ \\
\hline B & PSC & $\mathrm{PDT}^{*}$ \\
\hline C & PFL & $\mathrm{PL}^{*}$ \\
\hline D & PPB & PPB \\
\hline$E$ & PSC & PMDB $^{*}$ \\
\hline $\mathrm{F}$ & PDT & PDT \\
\hline$G$ & PMDB & PMDB \\
\hline
\end{tabular}

28 Em termos "nativos": "o seu grupo político não 'fez' nenhum Vereador". O fato de não ser eleito nenhum Vereador da coligação partidária que apoiou o Prefeito eleito mostra como está dissociado para o eleitor o voto dado ao Vereador e ao Prefeito a que a sua coligação partidária vincula-se (cf. VIEGAS, 1997, p. 148-149).

29 Prefeito de Araruama entre 1989 e 1992. 


\begin{tabular}{|c|c|c|}
\hline$H$ & PFL & PMDB $^{*}$ \\
\hline$I$ & $P S C$ & PL $^{*}$ \\
\hline$J$ & $P S T$ & PSDB $^{*}$ \\
\hline$K$ & PMDB & PDT $^{*}$ \\
\hline$L$ & $P P B$ & PPS $^{*}$ \\
\hline$M$ & $P S C$ & PDT $^{*}$ \\
\hline$N$ & $P F L$ & PPS $^{*}$ \\
\hline$O$ & $P S T$ & PSDB $^{*}$ \\
\hline$P$ & $P M D B$ & PPS $^{*}$ \\
\hline$Q$ & PDT & PDT \\
\hline
\end{tabular}

FONTE: o autor.

NOTA: * Mudou de partido durante o mandato.

1996, logo após as eleições ${ }^{30}$. Valladares foi o Prefeito entre 1992 e 1996. Teve onze vereadores da sua coligação eleitos, mas não elegeu seu sucessor na prefeitura. O Prefeito eleito não elegeu
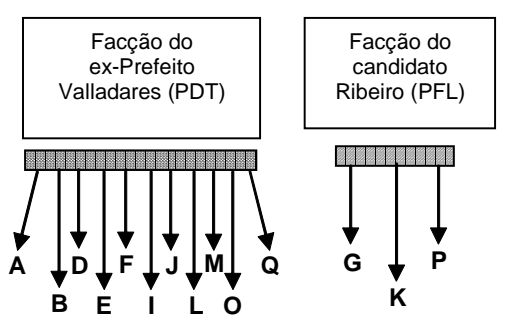

1997, início do mandato. As facções dispersaram-se e o Prefeito teve o apoio de todos os vereadores. Aos poucos, devido a alguns fatores - entre os quais o descontentamento com Prefei- nenhum Vereador de sua coligação partidária. O candidato Ribeiro foi eleito Prefeito em 2000, agora aliado a Valladares e ao Governador do Estado.

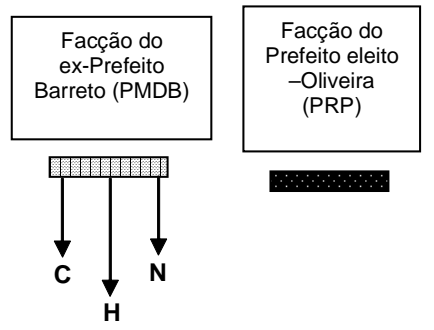

to quanto à distribuição desigual de recursos entre os vereadores -, alguns vereadores articularam-se em novas facções, como indica o esboço seguinte.

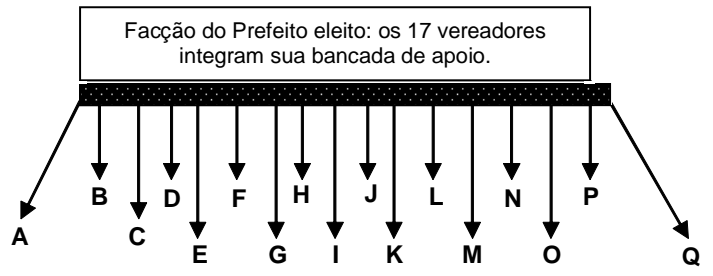

30 Os esquemas que se seguem visam apenas a dar forma visual à dinâmica faccional durante a legislatura 1997-2000. É preciso ter em mente que eles definem e recortam as facções de maneira mais nítida do que elas se afiguraram na realidade. Por outro lado, como já ressaltado, a posição pública assumida pelo Vereador (oposição ao governo) 
1998, ano de eleições estaduais e federais. O Vereador $\mathrm{O}$, que tinha relações pessoais com o Deputado Estadual R. Araújo, articulou com ele a montagem do "grupo ação", com seis vereadores, que agora se filiam ao Partido da Social-democracia Brasileira (PSDB) (três) e ao PMDB (três).
O rompimento da aliança do Prefeito com o Deputado fez que esses vereadores, liderados pelo Deputado, declarassem-se "oposição", ainda que alguns deles continuassem "beneficiando-se" do governo.
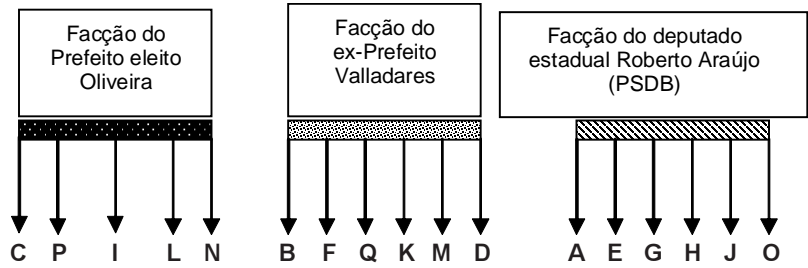

Bancada de apoio ao Prefeito ao longo do mandato.

$1997^{31}$

A facção do próprio Prefeito, formada no início de 1997, manteve-se estável durante todo o mandato. A facção do ex-Prefeito Valladares e do Deputado Araújo revezou-se na composição da bancada de apoio ao Prefeito. Durante o biênio 1997-1998 estiveram aliadas, em apoio ao governo, a facção do Prefeito e a facção do Deputado. Essa última deixou de integrar a bancada de apoio ao governo quando o Prefeito rompeu o compromisso de apoiar o deputado nas eleições que se realizariam em fins de 1998. Nesse mesmo período, foi realizada a eleição para a Mesa Diretora da Câmara - biênio 1999-2000 - e, devido a disputas internas (quebra de acordos estabelecidos entre alguns vereadores), produziu-se uma nova bancada de apoio, agora composta pela facção do exPrefeito Valladares e a do próprio Prefeito, que perdurou até o final do governo.

Em nenhum momento a fluidez das facções elidiu o apoio majoritário ao Prefeito na Câmara

muitas vezes não corresponde à sua posição real. O fato de uma das facções declarar-se oposição ao governo (como foi o caso do "Grupo Ação", no final de 1998) não significou que todos os vereadores fossem contra o governo. $\mathrm{Na}$ verdade, a minoria deles foi-o. Isso mostra, acima de tudo, a sedução que o apoio ao governo tem sobre os vereadores.

31 No ano de 1997, as facções não estavam definidas. Somente no final do ano elas tornaram-se mais delineadas, em decorrência da aproximação da campanha para as eleições estaduais e federais durante os quatro anos de mandato - apoio comprovado não só pela aprovação de quase todas as matérias enviadas ao plenário como também pela retração do papel fiscalizador da Câmara de Vereadores sobre as ações do Executivo. Como observou um dos integrantes da bancada de apoio ao governo, ainda em 1997, "a Câmara deu suporte, ainda que com o silêncio, ao senhor Prefeito" (LOPEZ, 2001, p. 89).

A atração que o Executivo exerce sobre os vereadores resulta da configuração do sistema político que articula eleitores, vereadores e o Prefeito. As alianças verticais vinculam o eleitor ao Vereador e este, no interesse de atender aquele, submete-se às imposições do Executivo, prérequisito para a obtenção das benesses.

Se ao Executivo interessa aprovar os seus projetos e leis, bem como diminuir o ímpeto fiscalizatório da Câmara, aos vereadores interessa obter os benefícios concedidos pelo Executivo, sem o que vêem ameaçadas suas capacidades de atendimento ao eleitor. A lógica da dinâmica relacional entre os vereadores e o Executivo é coerente: aqueles concedem carta branca ao Prefeito para aprovar matérias de seu interesse e recebem, em troca, o apoio material necessário ao atendimento aos eleitores. $\mathrm{O}$ aspecto crucial é, portanto, o controle do acesso dos vereadores aos recursos públicos de acordo com a posição de cada um em relação ao Executivo. Dessa forma, apoiar o governo, aprovar seus projetos e 
desconsiderar as irregularidades administrativas são pré-condições para o acesso aos benefícios que estão sob o seu controle. Essa é a atração que incita a adesão ao governo. "O Vereador é hoje um grande assistente social, por culpa do próprio sistema que é ineficiente no atendimento à demanda social. Nesse atendimento à demanda social [o Vereador] precisa de ajuda. E aí ele vai cair onde? Geralmente lá, na mão do Poder Executivo, que é quem tem a chave do cofre, quem pode ajudar com a doação de um terreno, com material de construção, com melhoras em um determinado bairro.

Para atender à demanda social, depende da ajuda do Poder Executivo. [...] a gente escorrega para todo lado: pede ajuda aos amigos para a gente poder ajudar o próximo [...]. Mas, geralmente, as pessoas [vereadores] vão se encostando, vão se tornando amigas do Poder Executivo, e aí vai dando a governabilidade dele, aí vai surgindo aquela história de que é difícil ver uma Câmara oposicionista, genuinamente oposicionista.

O que a gente observa é que o Executivo tem um poder muito maior do que o Legislativo. Eu tenho que fiscalizar. À medida que eu fiscalizo, se eu não estou atuando em comum acordo com o Executivo, daqui a pouco eu não tenho direito a nada. Se eu mandar uma pessoa lá na Secretaria para pedir um exame e for com o meu pedido, não consegue nada. Se eu mandar à Secretaria de Educação para pedir uma vaga, que é direito do aluno, para estudar em uma escola, não consigo nada" (idem, p. 90).

"Apoiar" o Executivo significa coisas diversas: votar as matérias de sua autoria encaminhadas ao Legislativo; "não falar mal do governo" publicamente, seja em plenário ou nos órgãos da imprensa local e, acima de tudo, não exercer a fiscalização dos atos do poder Executivo ${ }^{32}$ - o que é atribuição da Câmara ${ }^{33}$. Em troca, o Vereador

32 O que implica desconsiderar as irregularidades administrativas, malversação de recursos públicos, contratações irregulares de funcionários públicos e outras improbidades.

33 Cf. a Lei Orgânica Municipal, Art. 32, inciso XXII: "Fiscalizar e controlar os atos do Poder Executivo, incluídos os da Administração Indireta” (ARARUAMA, 1990). tem a possibilidade de 1) dispor de uma cota de nomeações de pessoas em cargos públicos, 2) ver parte de suas indicações atendidas pelo Executivo, 3) não sofrer restrição no seu acesso às secretarias da administração e 4) ver seu nome vinculado às obras realizadas em seu reduto.

Um Vereador dá-nos um exemplo prático: "Logicamente, o Vereador que faz parte da bancada do Prefeito tem franquia a tudo na prefeitura. $\mathrm{O}$ atendimento: as portas ficam abertas para o atendimento. Na realidade, o Vereador é um $\mathrm{em}$ preendedor das ações nas comunidades. Vou dar um exemplo. Hoje, o distrito de Lagoinha não tem nenhum Vereador que o represente. Eu fui o Vereador mais votado em Lagoinha. Então, a tendência é que eu venha a fazer um trabalho social, um trabalho político em Lagoinha. Até pelo grupo de pessoas que me apoiaram lá, que estão esperando isso de mim. Para isso eu preciso estar afinado com o Prefeito. Caiu lá, essa semana, uma ponte. Uma ponte que dá acesso ao centro do bairro. Se eu não tiver um bom relacionamento com o Prefeito, ele vai acabar fazendo aquela obra e eu nem sequer vou ser citado como empreendedor daquele projeto. Porque o Vereador não pode executar nenhuma obra. Ele indica. Quem executa é o Prefeito" ((idem, p. 91; sem grifos no original).

"Eu sou de Livramento [um bairro do Município] e sou oposição ao Prefeito, mas há o Vereador Lúcio que é de Itaqui, bairro muito próximo de Livramento, que é do [da bancada de apoio ao] Prefeito. Então, o Prefeito vai fazer uma obra em Livramento e diz: "Olha, Lúcio, solicita [a obra] aqui para mim [solicitação que é feita por meio da indicação].” Aí, o Lúcio solicita a obra, o Prefeito vai lá e faz. Se for eu que solicitar a obra, ele não faz. Ou, então, ele espera um pouco e pede para o Lúcio, depois, solicitar a obra de novo. Ele vai lá, pega o microfone na hora de inaugurar: 'Fulano de Tal pediu a obra ...' e faz um monte de elogios ao Lúcio" (idem, p. 92).

Sem apoio do Executivo, o Vereador está impedido de exercer a função que julga fundamental, i. e., "empreender as ações nas comunidades". $\mathrm{O}$ que está em jogo não é propriamente exercer a função legislativa, mas responder às expectativas da comunidade, "que está esperando" realizações, pouco importando a conduta política do Vereador em relação ao Executivo: "Eu, na administração passada, fiquei na oposição. Não era íntimo do 
Executivo. E passei quatro anos numa dificuldade, convencendo pessoas de que eu não tinha culpa de que as minhas solicitações não eram vistas pelo Prefeito. Mesmo assim, eu sobrevivi" (idem, p. 91).

Não estar ao lado do Prefeito implica custos políticos altos e, nesses termos, ter um bom desempenho político em tais circunstâncias é uma provação ("mesmo assim, eu sobrevivi").

A concepção de que a bancada de apoio ao Prefeito deve ter prioridade sobre as demais é tomada como um dado natural, tanto pelos vereadores ("logicamente...") quanto pelo próprio Executivo. Um assessor direto do Prefeito ressaltou que, não podendo atender a todos os pedidos que são encaminhados pelos vereadores, o Prefeito "evidentemente prioriza o atendimento aos que apóiam". "Mesmo porque", continua o assessor, questionando-me, "você não conhece aquele ditado que diz que 'aos amigos a gente dá tudo e aos inimigos a lei'?".

Dar apoio ao Prefeito significa ter acesso aos recursos indispensáveis para a atividade cotidiana do Vereador, para o seu trabalho de atendimento. Mas a oposição ao Prefeito tem critérios ambíguos: muitas vezes, é e não é oposição. Publicamente, certos vereadores declaram-se opositores (sobretudo quando o governo tem pouca popularidade), mas nos "bastidores" e nas votações estão com o governo. É o caso de dois vereadores que, a despeito de publicamente se declararem oposição, possuíam boa relação pessoal com o Gabinete do Prefeito, tinham "amizade pessoal" com a Chefe de Gabinete e suas demandas eram atendidas. Um outro Vereador nota, referindo-se a esses dois: "[...] quem mais se beneficiou do governo ultimamente foram Charles e Lauro que, mesmo sendo de oposição, têm acesso ao Reinaldo [Chefe de Gabinete do Prefeito]. Amizade pessoal que eles têm com ele e com o Prefeito" (ibidem).

Nem sempre a oposição é um mau negócio, do ponto de vista da obtenção de benefícios públicos. Oposição que também é ambígüa, dado que dificilmente aprofunda o ímpeto fiscalizatório. Constitui-se mais em instrumento de pressão sobre o Executivo. Como mencionou um Vereador da bancada de apoio ao governo: "Eu sei aqui de vereadores que estão na oposição que têm muito mais benefícios do que eu, dentro da prefeitura; têm muito mais abertura, são atendidos com mais rapidez. Por quê? Porque falam mal do governo. "Vamos tapar a boca de Fulano porque ele fala demais'. Aí, tem esse benefício" (idem, p. 93).

Deve-se enfatizar que o Prefeito tinha uma personalidade sui generis, evasiva, que muitas vezes frustrava as expectativas dos vereadores, por "falta de palavra", por "falta de compromisso" para cumprir acordos firmados, razão de numerosas indisposições entre alguns membros da Câmara e o chefe do Executivo ${ }^{34}$. Entre as várias críticas feitas pelos vereadores à conduta pessoal do Prefeito, uma delas salientava que somente pelas sucessivas quebras de compromisso ele não teve plena sustentação política na Câmara durante os quatro anos: "A palavra-chave é a pessoa não ter credibilidade. $\mathrm{O}$ homem público precisa ter credibilidade, $[\ldots]$ as pessoas precisam ter certeza de que o que ele trata, vai cumprir. E o Prefeito é uma pessoa que trata sentado e não cumpre em pé. Ele é uma pessoa que trata, mas você não pode nunca chegar à sua comunidade e dizer que ele vai cumprir isso, isso e isso, porque você está arriscando ficar de cara inchada lá. Então, por isso ele não tem essa sustentação da maioria absoluta da Casa.

O Vereador, quando é da bancada do Prefeito, a tendência dele [do Prefeito] é atender, dar prioridade aos pedidos. Só que esse governo que está terminando agora é um governo que não tem consistência. Você tanto pode fazer parte do governo dele quanto não fazer parte que ele terá a mesma posição. Porque ele é um Prefeito que trata e não cumpre. Ele trata agora uma coisa com você

\footnotetext{
34 O Prefeito já foi Vereador. Como destaca Viegas (1997, p. 141), "ao longo de seus mandatos [como Vereador], reforçou a figura de 'pai dos pobres', fazendo toda espécie de favores típicos da política assistencialista: doação de remédios, viabilização de internações, transporte de pessoas do interior, empréstimo de caminhão de mudanças etc. [...] Sua atuação como Vereador pautava-se muito mais por moldes populistas do que pelos padrões individualistas da democracia. À defesa dos direitos e à construção da cidadania contrapunham-se os favores, as relações pessoais, as trocas. Sua eleição para Prefeito, por esse viés, significaria a ampliação desses favores, consolidada em promessas de campanha do tipo: criação de uma farmácia popular, construção de um albergue e de creches, doação de cestas básicas mensais aos trabalhadores da Prefeitura que ganhassem um salário-mínimo".
} 
e amanhã não cumpre. Então, é uma pessoa difícil. É um fato inédito nós termos hoje um Prefeito que trata e não cumpre. Ele combina com você agora e daqui a meia hora a palavra dele é descumprida" (idem, p. 94).

A inconstância da palavra do Prefeito como chancela de compromissos informais com os vereadores motivou inclusive que o acordo 35 entre o grupo do ex-Prefeito Valladares (seis vereadores) e o grupo do Prefeito para a eleição da Mesa Diretora da Câmara Municipal, para o biênio 19992000, fosse estabelecido com o líder do governo e não com o próprio Prefeito. O líder é a pessoa que detém maior prestígio no Executivo e foi o mediador entre o grupo do ex-Prefeito e o Prefeito da época, devido à imprevisibilidade da palavra do último.

Destacar a personalidade sui generis do Prefeito é importante para mostrar que, mesmo atuando de modo não condizente com as expectativas dos vereadores, quebrando acordos, infringindo regras morais de conduta, o Prefeito nunca deixou de ter a sustentação necessária na Câmara ${ }^{36}$.

A dependência do Legislativo em relação o Executivo reflete, por outro lado, os "dilemas da ação coletiva". Um dos vereadores descreve como a possibilidade da ação coletiva dos vereadores frente ao Executivo esbarra no interesse de maximização dos ganhos pessoais: "Quando nós [vereadores] nos elegemos, nós sentamos em uma roda e dissemos assim: 'nós vamos ser uma

$\overline{35} \mathrm{O}$ acordo estabelecido entre o grupo do Prefeito (cinco vereadores) e o grupo do ex-Prefeito (seis vereadores), conquanto alguns vereadores tenham negado, resultou na obtenção de, pelo menos, alguns empregos na Prefeitura Um dos vereadores observou "que ele [o Chefe de Gabinete] havia prometido alguns empregos, algumas colocações para os vereadores".

36 Entre as reprováveis condutas do Prefeito está, por exemplo, o comentário que ele fez sobre os vereadores dizendo que "era mais fácil comprar um Vereador do que um pão na padaria". Em discurso em uma escola do município ele disse, na presença de alguns vereadores: "Meu partido não elegeu nenhum Vereador, porém hoje tenho os 17 aqui na minha mão. Dei a cada um deles 16 contratos [de emprego] e só eles estão autorizados a contratar qualquer pessoa" (cf. EDITORIAL, 1997, p. 2).
Câmara forte'. Nós vamos conduzir, sabendo das dificuldades que o Prefeito teria, nós íamos conduzir o Executivo. Tínhamos tudo para ser uma grande Câmara, com um poder nunca visto em Araruama ${ }^{37}$. Não foi porque começaram a existir os interesses pessoais. O seu Fulano [nome do Vereador] foi para lá porque o pai foi chamado para ser Secretário. Começou com ele, depois foi o Vereador B, depois foi outro, outro e, quando vimos, estávamos em três grupos dentro da Câmara" (idem, p. 97) ${ }^{38}$.

Da mesma forma, outros vereadores comentam: "Quem dá governabilidade é a Câmara. Mas é que eles [os vereadores] não entendem. Se você dá governabilidade, por que você não pode estar no mesmo patamar do Prefeito? Poderia hoje estar todo mundo com poder, mas esse racha e essa falta de sabedoria de que nós temos força se todo mundo se unir é que faz o Vereador ficar fraco, ficar fazendo só assistencialismo, não exercer as suas funções, não ter voz e não brigar frente a frente com o governo. Porque quase $90 \%$ está refém. Se você está refém, você não pode ter forças. Você está aniquilado" (ibidem).

"É o individualismo. De repente eu penso assim, você pensa assim, mas o terceiro não pensa. Aí, eu começo a pensar: o outro está tomando o meu espaço. E o eleitor que bate aqui é a mesma coisa: não existe uma lei que diz que você, em campanha, não pode dar isso ou aquilo? Eu não dou. E se todo mundo não desse? Ninguém ia pedir. Só que eu não dou, você não dá, outro não dá, mas vem outro e dá. E o bonzinho é sempre o outro" (idem, p. 98).

"A Câmara é autônoma, mas há os favores. O Vereador quer seu 'oxigênio'. A sua sobrevivência é aquilo que ele faz pelo povo. Se o Prefeito atendeu, ele fica, não é? Mas deveria ser diferente,

37 Deve ser lembrado que o Vereador provavelmente tem em mente o fato de que haviam sido eleitos onze vereadores do grupo do ex-Prefeito, dos quais ele era um.

38 Observe-se que nessa passagem o Vereador mostra como as ações políticas, a formação de grupos políticos e facções ocorrem sem qualquer consideração pelas filiações partidárias, que só se tornam relevantes em períodos eleitorais. Descreve um comportamento político orientado em termos puramente voluntaristas e personalizados. 
porque você não está pedindo para você, você está pedindo para a comunidade. Então, eu vou ali e consigo uma ambulância para remover um paciente para o Rio. É uma obrigação do Prefeito. Para que serve uma ambulância? Para isso. Então, não é porque o Prefeito cedeu-me uma ambulância que sou obrigado a votar em tudo que ele manda para mim. Certo? Mas aí é que vem aquela questão: o Executivo, às vezes, não entende isso" (ibidem).

Quando avaliam os motivos por que não atuam coletivamente, as respostas dos vereadores quase sempre recaem na ausência de confiança mútua. Deixar de receber favores do Prefeito (materializados no atendimento de pedidos de pequenas obras) implica abrir mão de benefícios (políticos) cruciais para o exercício da política cotidiana do Vereador, a menos que todos façam-no conjuntamente.

Do ponto de vista dos vereadores, se a Câmara não consegue exercer o poder que tem, o problema não está na instituição em si, mas na lógica dos agentes que a compõem. Não há motivação para abrir mão dos benefícios que o apoio ao governo representa, pois: a) isso significa a diminuição da força política do Vereador, dado que a população não reconhece o trabalho parlamentar, e, por isso, b) dispensar as benesses do Executivo demandaria um acordo mútuo que assegurasse a todos que nenhum deles abriria mão da união, da imposição de políticas ao Executivo e da fiscalização dos seus atos, o que se torna inviável pela desconfiança recíproca entre os atores ${ }^{39}$.

Não há incentivo para que se abandone a corrida pelas dádivas distribuídas pelo Executivo. A estratégia da não-cooperação apresenta um equilíbrio estável e não há incentivo para que os vereadores busquem alternativas que impliquem maior colaboração, por mais que isso represente a manutenção dos costumeiros padrões de ação política que condenam.

Nesse sentido, os valores culturais parecem ter profunda relevância ao atuarem sobre a

39 É preciso levar em conta que não só os vereadores eleitos mas também outras pessoas, potenciais candidatos, realizam durante todo o tempo trabalho assistencial, o que representa motivação adicional para que não se dispense a ajuda do Executivo. Nas eleições municipais de 2000, o Município teve 328 candidatos a Vereador. estrutura institucional que define as relações entre o Executivo e o Legislativo do Município.

A ordenação institucional é determinante para explicar o padrão das interações entre os componentes da esfera política, produzindo incentivos específicos que reforçam certos padrões de interação entre Executivo, Legislativo e eleitores. Mas - é preciso sempre relembrar - as instituições são submetidas a um conjunto de valores e representações sociais que parecem formatar a maneira pela qual mudanças institucionais ou transformações sócio-econô-micas ganham corpo: no funcionamento cotidiano dos poderes instituídos - sobretudo Legislativo e Executivo -, nas relações dos agentes políticos entre si e com os eleitores, no comportamento de funcionários. Enfim, nas relações quotidianamente estabelecidas na esfera política municipal.

Vejamos os argumentos de Pralon e Ferreira (1998). Ao analisar o caso específico da Câmara Municipal da cidade de São Paulo, os autores argumentam que, após a Constituição de 1988, a maior autonomia financeira dos municípios em relação ao governo estadual, alguns novos poderes institucionais conferidos às câmaras municipais em relação aos Executivos locais - como o poder de apresentar emendas ao Orçamento - e a proximidade que os membros do Legislativo municipal experi-mentam em relação aos eleitores ${ }^{40}$ resultaram em um Poder Legislativo mais forte vis-à-vis o Executivo. A pesquisa em Araruama mostrou que ali isso não se aplica. A proximidade dos eleitores com os vereadores, ao contrário, pressiona os parlamentares a buscar o Prefeito a fim de atender às demandas do eleitorado. A relação criada, tanto entre eleitores e vereadores quanto entre vereadores e o Prefeito, é de natureza predominantemente clientelista. Aos vereadores é dada pouca margem de escolha, de acordo com a lógica da competição entre eles. Segundo os autores, "o Prefeito, para governar, depende do Parlamento em maior medida do que o Executivo estadual. Isso porque os vereadores constituem o principal canal de representação política na sua base, ao contrário dos deputados, que sofrem a concorrência dos poderes locais,

40 No caso de Araruama, a interação é, na maioria das vezes, face a face. 
além de estarem geograficamente afastados de sua base" (idem, p. 76).

A julgar por Araruama, dois pontos deveriam ser adicionados à passagem acima. Em primeiro lugar, se os vereadores são os principais canais de representação política na sua base, eles só mantêm este status pela aliança construída com o Executivo - que tem, para usar as palavras de Victor Nunes Leal (1997, p. 64), "o cofre das graças e o poder da desgraça". Por outro lado, a disputa pela preferência dos eleitores em determinado bairro ou região do município é acirrada, não tanto entre os membros do Legislativo, mas entre estes e os potenciais candidatos em busca de sua eleição.

Pode-se argumentar que o nível de desenvolvimento econômico sempre é uma variável importante quando se busca explicar padrões de relacionamento político de natureza clientelística. De fato é. Mas a idéia de que essa variável, aliada à racionalização das instituições burocráticas, produziria uma radical mudança nas ideologias cívicas e transformaria a natureza da relação entre vereadores e eleitores - ou mesmo entre poder público e cidadãos - não se mostrou verdadeira em Araruama.

A observação empírica ressalta que as relações clientelísticas não antagonizam o desenvolvimento das instituições burocráticas ou as ideologias cívicas. A respeito desse aspecto, Reis (1988) oferece indicações sugestivas. Em estudo realizado em um Município do interior de Minas Gerais, a autora observa que a solidariedade social baseada nas relações de patronagem articula-se com as instituições burocráticas, criando uma situação antes de imbricamento que de antagonismo. Para a autora, embora a ampliação dos direitos sociais e das instituições públicas (em oposição ao poder privado), no âmbito municipal, tenha contribuído para reforçar o sentimento de pertencimento a uma coletividade mais ampla - a sociedade nacional -, a percepção da necessidade da intermediação política como via de acesso a esses benefícios manteve a mesma força. A representação dos habitantes diferia, contudo, quanto à concepção acerca dos "novos políticos", vistos como representantes do Estado, com acesso ao governo e aos políticos das esferas superiores. Se os habitantes passavam a identificar-se com o todo mais amplo e a olhar as ligações políticas entre os níveis local, estadual e federal como importantes, a forma pela qual concebiam o acesso aos recursos provenientes dessa ligação continuava a ser, essencialmente, clientelística. "Quando nos detemos para examinar o funcionamento dessas novas agências burocráticas, é bastante evidente que o recurso à patronagem é tão natural como costumava ser nos velhos tempos" (idem, p. 209). Os benefícios não eram vistos como direitos outorgados pelo Estado, mas como dádivas obtidas por intermediação política. "Os novos líderes locais 'representam', para seus seguidores, o Estado todo-poderoso que distribui favores; não é o cidadão que se faz representar para assegurar junto à autoridade pública seus legítimos direitos" (ibidem). Os bens e serviços públicos continuavam a ser distribuídos pela via dos mecanismos de patronagem. Esse aspecto é fundamental. Maior autonomia financeira dos municípios ou autonomia administrativa para decidir como e onde alocar recursos não se traduzem, necessariamente, em diminuição das relações clientelísticas.

Como indicou Reis, se a crescente importância conferida às instituições públicas e aos vínculos estabelecidos entre o município e o estado representava a introjeção de ideologias cívicas, calcadas no sentimento de pertencimento ao Estado nacional, elas não elidiam a natureza clientelista da relação entre os eleitores e os políticos locais: "substituindo os antigos coronéis, a burocracia estatal não tem encontrado competidores entre outras instituições ou grupos que desafiem suas estratégias e táticas de modo a forçar a adoção de um padrão minimamente universalista" (idem, p. 216). Os direitos sociais, bem como a crescente disponibilidade de outros recursos materiais, continuavam a ser apropriados para distribuição sob a forma de favores.

A ordenação política em Araruama pode, com algumas distinções, ser pensada nesses termos. Por mais que os bens e serviços públicos sejam mais universalizados, na maior parte das vezes o acesso a eles passa pelos canais da distribuição clientelística. No nível local, a representação social do Vereador como distribuidor legítimo de benefícios é bastante vigorosa.

Quanto à interação entre políticos locais e eleitores, as eleições municipais de 2000 foram indicativas de que o desenvolvimento político caminha no sentido de um comportamento mais pragmático, tanto dos políticos quanto dos eleitores. A tônica da campanha referia-se à quase 
inviabilidade de uma candidatura (a Prefeito ou a Vereador) sem recursos financeiros e, cada vez mais, essa é uma das variáveis fundamentais para medir as possibilidades políticas de cada candidato. $\mathrm{O}$ voto gradativamente deixa de ser a expressão de amizade pessoal para ser medido em termos monetários. Sintomaticamente, a compra de votos assumiu um caráter quase público nas últimas eleições. Tudo indica que a mercantilização do voto vai acentuar-se ${ }^{41}$.

Como última sugestão especulativa, pode-se fazer analogia com o argumento de Blok (1988), que, analisando a sócio-gênese da máfia em um pequeno povoado siciliano, mostra que o desenvolvimento da máfia não antagonizava o processo de constituição do Estado italiano, nem representava somente um sistema paralelo ao governo: ela estava imbricada nele e era sua dependente, constituindo a expressão da forma específica pela qual ocorreu o processo de formação do Estado na Itália $^{42}$ (BENDIX, 1998, p. XXI).

Igualmente, pode-se pensar que a maneira por que se tem acesso às instituições públicas, bem como aos bens e recursos do Estado, assume sua feição clientelista não apesar da expansão do Estado ou do desenvolvimento da burocracia, mas como parte deles. A ampliação dos direitos de cidadania, o desenvolvimento burocrático e a competição partidária não representam a mudança dos laços de dependência vertical se o controle dos canais de distribuição não se altera e, sobretudo, se as representações sociais sobre a atividade política permanecem. A estrutura do sistema político que procurei descrever aqui se apóia fortemente nas troca de favores, nas redes de dependência pessoal e na solidariedade clientelista - de resto, padrões de relacionamento fundamentais em nossa sociedade e já fartamente analisados pelas Ciências Sociais brasileiras. Mesmo a competição partidária, no âmbito municipal, não estimula a transformação desses traços, dado que existem regras implícitas dentro das quais todos operam e pelas quais todos se moldam. Nesse sentido, ela não tem estimulado mudanças substanciais na estrutura de ordenação das instituições públicas no nível municipal, embora uma análise histórica possa revelar muitas dimensões que são excluídas de um estudo baseado apenas em dados recentes acerca da política municipal.

Felix G. Lopez (fglopez@ig.com.br) é Mestre em Sociologia pela Universidade Federal do Rio de Janeiro (UFRJ) e doutorando em Sociologia na mesma instituição.

41 Farias (2000) argumenta que o clientelismo político em
geral e o clientelismo estatal, em particular, são dimensões
intrínsecas da democracia no sistema capitalista. Antes de
resultar do subdesenvolvimento econômico e social, da
pobreza ou de privações de natureza econômica, o
clientelismo é resultado de uma estrutura (capitalista) que
tende a tornar mercantilzável qualquer comportamento ou
bem que possa assumir valor, como o voto. No seu
específico estudo de caso, o autor argumenta que a passagem
do grande latifúndio pré-capitalista para o agricultura
mercantilizada, em que a mão-de-obra torna-se assalariada,
produziu uma migração correspondente das práticas
políticas derivadas do coronelismo para práticas de natureza
clientelista. Relacionar o clientelismo à democracia
capitalista de modo causal implicaria demonstrar que ele
existe em nível significativo em todas as sociedades
capitalistas, o que não é verdadeiro.
42 "Mafia is in no sense a residue of the lawless past. It is
an outgrowth of the particular form that the process of
state formation took in Italy. It grew precisely because
national systems of power - and the connections between
the two were few, fragile, and open to monopoly. For a
long period the central governments had to work through
their rivals, the very landlords and mafiosi they had helped to create. $[\ldots]$ A splendid dialectic. And one which renders inappropriate any idea of political development as the continuous, self-directed struggle of a particular government over the forces of tradition, corruption, particularism. State-formation, then, is a great and powerful process, but it is not immanent in particular governments, is not unidirectional, and is not, in any simple sense of the words, a displacement of the 'traditional' by the 'modern"" ["A mafia não é, em nenhum sentido, um resquício de um passado sem lei. Ela é um resultado da forma particular que o processo formador do Estado na Itália assumiu. Ela cresceu precisa-mente devido aos sistemas nacionais de poder - e as cone-xões entre os dois eram poucas, frágeis e sujeitas a mono-pólio. Por um longo período os governos centrais tiveram que lidar ["work through"] com seus rivais, os senhores de terras e os mafiosos que eles ajudaram a criar. [...] Uma dialética esplêndida - e que inapropriadamente rende uma idéia do desenvolvimento político como a luta contínua e autodirigida de um governo particular sobre as forças da tradição, corrupção e do particularismo. A formação do Estado, então, é um grande e poderoso processo, mas não é imanente em governos particulares, não é unidirecional e não é, em qualquer sentido comum das palavras, um deslo-camento do 'tradicional' pelo "moderno"" - N. R.]. 


\section{REFERÊNCIAS BIBLIOGRÁFICAS}

BAILEY, F. G. 1971. Gifts and Poison: The Politics of Reputation. Oxford : B. Blackwell.

BARBOSA, J. L. D. 1996. Naquele tempo era uma família só : uma análise sobre família e mudança social no município de Araruama-RJ. Rio de Janeiro. Dissertação (Mestrado em Sociologia). Universidade Federal do Rio de Janeiro.

BARNES, J. A. 1987. Redes sociais e processo político. In : FELDMAN-BIANCO, B. (org.). Antropologia das sociedades contemporâneas : métodos. São Paulo : Global Universitária.

BENDIX, R. 1995. Introduction. In : BLOK, A The Mafia of a Sicilian Village, 1960-1960 : A Study of Violent Peasant Entrepreneurs. Nova York : Waveland.

BEZERRA, M. O. 1995. Corrupção : um estudo sobre poder público e relações pessoais no Brasil. Rio de Janeiro : Relume DumaráAssociação Nacional de Pesquisa e Pósgraduação em Ciências Sociais.

1999. Em nome das "bases" : política, favor e dependência pessoal. Rio de Janeiro : Relume-Dumará.

BLOK, A. 1995. The Mafia of a Sicilian Village, 1960-1960 : A Study of Violent Peasant Entrepreneurs. New York : Waveland.

BOURDIEU, P. 1996. Marginália : algumas notas adicionais sobre o dom. Mana, Rio de Janeiro, v. 2 , n. 2 , p. $7-17$, out.

CHAVES, C. A. 1996. Eleições em Buritis : a pessoa política. In : PALMEIRA, M. \& GOLDMAN, M. (orgs.). Antropologia, voto e representação política. Rio de Janeiro : Contracapa.

DAMATTA, R. 1987. Cidadania : a questão da cidadania num universo relacional. In: A casa e a rua. Rio de Janeiro : Guanabara.

1997. Carnavais, malandros e heróis : para uma Sociologia do dilema brasileiro. Rio de Janeiro : Rocco.

1998. O que faz o brasil, Brasil? Rio de Janeiro : Rocco.

DINIZ, E. 1982. Voto e máquina política : patronagem e clientelismo no Rio de Janeiro. Rio de Janeiro : Paz e Terra.

FARIAS, F. P. 2000. Clientelismo e democracia capitalista : elementos para uma abordagem alternativa. Revista de Sociologia e Política, Curitiba, n. 15 , p. 49-66, nov.

GRAZIANO, L. 1977. Patron-Client Relationships in Southern Italy. In : SCHMIDT, S. W. (ed.). Friends, Followers and Factions : A Reader in Political Clientelism. Berkeley : University of California.

KUSCHNIR, Karina. 1993. Política e mediação cultural : um estudo da Câmara Municipal do Rio de Janeiro. Rio de Janeiro. Dissertação (Mestrado em Antropologia Social). Universidade Federal do Rio de Janeiro.

1995. Em troca do mandato : a relação entre vereadores e seus eleitores. Comunicações PPGAS, Rio de Janeiro, n. 5, p. 61-84, mar.

1998. Política e sociabilidade : um estudo de Antropologia Social. Rio de Janeiro. Tese (Doutorado em Antropologia Social). Universidade Federal do Rio de Janeiro.

LANDÉ, C. 1977a. Introduction : The Dyadic Basis of Clientelism. In : SCHMIDT, S. W. (ed.). Friends, Followers and Factions : A Reader in Political Clientelism. Berkeley : University of California.

1977b. Networks and Groups in Southeast Asia : Some Observations on the Group Theory of Politics. In : SCHMIDT, S. W. (ed.). Friends, Followers and Factions : A Reader in Political Clientelism. Berkeley : University of California.

LEAL, V. N. 1997. Coronelismo, enxada e voto : o município e o regime representativo no Brasil. $3^{\mathrm{a}}$ ed. Rio de Janeiro : Nova Fronteira.

LOPEZ, F. G. 2001. As relações entre Executivo e Legislativo no Município de Araruama-RJ. Rio de Janeiro. Dissertação (Mestrado em Sociologia). Universidade Federal do Rio de Janeiro.

MAYER, A. C. 1987. O significado dos "quasegrupos" no estudo das sociedades complexas. In : FELDMAN-BIANCO, B. (org.). Antropologia das sociedades contemporâneas : méto- 
dos. São Paulo : Global Universitária.

NUNES, E. 1997. A gramática política do Brasil : clientelismo e insulamento burocrático. Rio de Janeiro : Jorge Zahar.

PALMEIRA M. \& HEREDIA, B. 1996. Os comícios e as políticas de facções. In : Anuário Antropológico - 94. Rio de Janeiro : Tempo Brasileiro.

PALMEIRA M. 1996. Política, facções e voto. In : PALMEIRA M. \& GOLDMAN, M. (orgs.). Antropologia, voto e representação política. Rio de Janeiro : Contracapa.

PRALON, E. M. \& FERREIRA, G. N. 1998. Centralidade da Câmara Municipal de São Paulo no processo decisório. In : ANDRADE, R. C. (org.). Processo de governo no município e no estado : uma análise a partir de São Paulo. São Paulo : USP.

QUEIROZ, M. I. P. 1976. O mandonismo local na vida política brasileira. In : mandonismo local na vida política brasileira e outros ensaios. São Paulo : Alfa-Ômega.

REIS, E. P. 1988. Mudança e continuidade na política rural brasileira. Dados, Rio de Janeiro, v. 31 , n. 2 , p. $203-218$.

SAHLINS, M.. 1977. Economía de la Edad de Piedra. Madri : Akal.
SCOTT, J. 1977. Patron-Client Politics and Political Change in Southeast Asia. In : SCHMIDT, S. W. (ed.). Friends, Followers and Factions : A Reader in Political Clientelism. Berkeley : University of California.

SEBRAE-RJ. 1999. Desenvolvimento econômico sustentável - Araruama-RJ. Rio de Janeiro : Serviço de Apoio às Micro e Pequenas Empresas. Digit.

SECRETARIA MUNICIPAL DE CULTURADE ARARUAMA. 1992. Araruama : panorama de uma cidade. Araruama : digit.

SILVERMAN， S. 1977. Patronage and Community-Nation Relationships in Central Italy. In : SCHMIDT, S. W. (ed.). Friends, Followers and Factions : A Reader in Political Clientelism. Berkeley : University of California.

VIANNA, O. 1987. Instituições políticas brasileiras. Belo Horizonte : Itatiaia.

VIEGAS, A. C. C. 1997. Trocas, facções e partidos : um estudo da vida política em Araruama-RJ. Rio de Janeiro. Tese (Doutorado em Antropologia Social). Universidade Federal do Rio de Janeiro.

WOLF, E. 1974. Parentesco, amizade e relações patrono-cliente em sociedades complexas. $\mathrm{Ca}$ dernos de Antropologia, Brasília, n. 7, p. 1-26.

\section{OUTRAS FONTES}

CEI (Comissão Especial de Investigação). 1999. Resolução n. 31 : Relatório final. Araruama : Câmara Municipal de Araruama, 22fev.1999, protocolo n. 408 .

Editorial. 1997. Voz de Araruama, p. 2, 19.abr.

TCE. 2000. Finanças públicas : estado e muni- cípios. Rio de Janeiro : Tribunal de Contas do Estado. Digit.

ARARUAMA. 1990. Lei orgânica do Município. Disponível em http://www.araruama.rj-gov.br/ principal/leis-codigos.htm. Acesso em : 16.jun.2004. 